\title{
Television and electoral results in Catalonia
}

\author{
Iván M. Durán ${ }^{1}$ (D)
}

Received: 12 December 2016 / Accepted: 23 July 2018 / Published online: 6 August 2018

(c) The Author(s) 2018

\begin{abstract}
The television channel TV3 has played a controversial role in the Catalan politics since its creation in the early eighties for its alleged partisan bias and support for the Catalan secessionist movement. This paper examines the impact on electoral results stemming from the exposure to TV3 exploiting its staggered expansion across Catalan municipalities in the 1980s. We find that the introduction of TV3 increased voter turnout in the 1984 Catalan parliamentary election, but it did not have a significant impact on the share of votes received by Convergència $i$ Unió, the Catalan nationalist force that has been commonly associated with this channel since its foundation.
\end{abstract}

Keywords Voting behavior · Television · Natural experiment · Catalonia

JEL Classification L82 · D72 · C99

\section{Introduction}

The literature on the political economy of media has grown rapidly and several excellent surveys have already been written on this topic (DellaVigna and Gentzkow 2010; Prat and Strömberg 2013; Sobbrio 2014; Strömberg 2015). Nevertheless, most of the empirical research has thus far focused on highly consolidated democracies (e.g. the USA and Scandinavian countries) and some formerly authoritarian countries (e.g. Russia and East Germany). As Sobbrio (2014) points out, additional academic contributions are needed to provide empirical evidence on the effects of media in less explored institutional settings. Catalonia's political context, characterized by a long-

\footnotetext{
I am very grateful to Francesc Trillas for supervising this research. I am also grateful to Roxana Gutiérrez-Romero, Yarine Fawaz, Agustín Casas and Andreas Kyriacou for their valuable comments. Finally, I also thank the editor and two anonymous reviewers for their constructive comments, which helped me to improve the manuscript.
}

Iván M. Durán

ivanmduran@gmail.com; imduranp@unal.edu.co

1 Department of Applied Economics, Universitat Autònoma de Barcelona, Barcelona 08183, Spain 
standing secessionist conflict with Spain, is a newfangled case study to analyze the effect of a sub-national media such as TV3, which has had an alleged pro-independence bias, on political outcomes. This paper therefore contributes to the existing literature on the effect of media on politics by identifying to what extent voting results in Catalonia can be explained by exposure of individuals to TV3.

In recent years, TV 3 has been the subject of much controversy for its alleged support for the Catalan secessionist movement and partisan bias, which has seemingly favored the political coalition Convergència i Unió (CiU). The CiU was a federation of two political parties representing the Catalan nationalist ideology, created in 1978 and dissolved in 2015, that played a crucial role in the creation of the channel in the early 80 s as well as its direction since then. ${ }^{1}$

Given this increased political tension, in which TV3 seems to play a main role, it raises the question of to what extent voting results in Catalonia can be indeed explained by the exposure of individuals to this channel. Providing empirical support to the effect of TV3 over the last decade of political tension in Catalonia is still a challenge, due to the fact that the whole region has been covered by TV3 since the mid-80s, thereby impeding to sort out the self-selection problem. However, there is the possibility of taking advantage of a natural experiment exploiting the staggered expansion of the channel in the early 80s. Although it is true that the secessionist movement has been more vehement in the last decade, the effect of TV3 on Catalan politics may be traced back to the beginnings of the channel.

In fact, it is noteworthy that the emergence of TV3 in 1983 - that is, in the middle of the first two Catalan Parliamentary elections (1980 and 1984) after 40 years of dictatorship — precisely coincided with the consolidation of the $\mathrm{CiU}$ as the strongest political force in the region. The number of votes for the CiU rose from 754,448 in 1980 to $1,345,513$ in 1984, which represents an outstanding increment in the vote share from 28 to $47 \%$ (see "Appendix 1"). Admittedly, the increase in the CiU's vote share could have only been a consequence of the consolidation of the Catalan party system, which had been fragmented up until then. Nonetheless, the CiU is the party which exhibited the greatest vote share increase, which leads us to suspect about a possible effect of this channel on the individuals' electoral behavior, and thus raises the need for closer scrutiny of its role.

Exploiting a natural experiment based on TV3's staggered expansion across Catalan municipalities during 1983 and 1984, this paper looks into the effect of TV3 on the electoral results of the 1984 Catalan Parliamentary election. In particular, we analyze the effect of TV3's availability at the municipality level on two political outcomes of interest: voter turnout and the CiU's vote share. To do so, we implement a standard two-periods Difference-in-Differences (DiD) model. Additionally, we examine the impact of TV3's availability on other political parties competing in the same election, we analyzed the treatment duration effect of the channel on voter turnout and the CiU's vote share, and we estimate the persuasion rates.

As we will document later, although TV3 intended to cover the whole region of Catalonia in a short timeframe, even before the 1984 Catalan parliamentary election,

\footnotetext{
1 The controversy about the TV3 bias has been amply covered by both Spanish and international media. For instance, see "Catalan TV Network Reflects Separatist Fervor" by The Wall Street Journal on 8 January 2014.
} 
exogenous technical and logistical constraints presumably caused a delay in the timing of the introduction of TV3 across different municipalities. This implies that the presence of TV3 in only some municipalities is plausibly exogenous to political attitudes. This delay, however, did not necessarily change the ordering; that is, the initial assignation to TV3 is not random, but it responded to the spread of the channel from the center (Barcelona) to the periphery, in accordance to the availability of broadcast centers. Thus, the identifying assumption is that the TV3 staggered expansion is unrelated to other factors that influence political outcomes once we take into account relevant initial conditions of TV3 placement.

We find that the introduction of TV3 caused a significant increase in voter turnout in the 1984 Catalan parliamentary election, but we did not find evidence that the channel had indeed influenced voting for CiU. Specifically, municipalities exposed to TV3 experienced a larger change in voter turnout between 1980 and 1984, this effect oscillates from 6.8 to 8.4 percentage points, depending on the specification. Thus, at least in this setting, TV3 apparently played a role by increasing electoral participation, which is a positive expected effect of a media outlet in any democracy. On the other hand, there is no evidence to conclude that the channel had an effect on the vote share of CiU in this election. Thus, even though the CiU's vote share showed a considerable growth between 1980 and 1984 (see "Appendix 1"), it cannot be said that this increment is attributable to TV3, but it was seemingly a phenomenon that covered all of Catalonia.

The rest of the paper is organized as follows. Section 2 presents a brief case contextualization. Section 3 reviews some theoretical and empirical literature on media, voting turnout and political persuasion, and we pose the working hypotheses. Section 4 presents the available data. Section 5 explains the empirical strategy. Section 6 shows the main econometric results. Finally, Sect. 7 presents some final remarks.

\section{The timing of the TV3 entry}

Once the Franco dictatorship ended in 1975, Catalan society started a long recovery process of its identity and language. Jordi Pujol, leader of the CiU and president of the Catalan government from 1980 until 2003, promoted two laws so that the Catalan language started to be used in all region within the shortest possible timeframe: the Law on Language Normalization, that regulates the Catalan in teaching, ${ }^{2}$ and the Law that created the Catalan Corporation of Radio and Television (Hierro 2012: 90). The idea of implementing a Catalan language normalization policy and the creation of media system did not only come from the CiU. With some nuances, this aim was also shared by other nationalist parties in Catalonia, however the CiU was the one that ultimately led this project and founded the Corporation in 1983. Since then, this political coalition has mainly managed the Catalan media.

\footnotetext{
2 See Clots-Figueras and Masella (2013) and Woolard and Gahng (1990) about the effect of teaching in Catalan language on the nationalist sentiment.
} 
Although the CiU wanted to take TV3 to the whole of Catalonia-and even to other Catalan-speaking regions out of Catalonia-in the shortest time possible, the first broadcasting, which took place on 10 September 1983 through the Tibidabo broadcast center, only reached out Barcelona (the capital city) and some surrounding districts. Subject to the economic and technical constraints faced by a project of this magnitude, ${ }^{3}$ the remainder of Catalonia was gradually covered during the next two years by setting new broadcasts and transponder centers.

Drawing on information provided by Montero (1987) and a variety of newspaper articles by La Vanguardia from 1983 to 1985 on the TV3 coverage (see “Appendix 2"), we identify the timing of the TV 3 entry in the municipalities of Catalonia. TV3 set three important broadcast centers before April 1984, the Catalan parliamentary election month: Alpicat on 31 December 1983 to cover the districts of Garrigues, Noguera, Segarra, Segrià, and Urgell. Rocaborda on 16 January 1984 to cover Alt Empordà, Baix Empordà, Gironès, and Selva. And La Mussara also on 16 January 1984 to cover Alt Camp, Baix Camp, and Tarragonès. Furthermore, TV3 set some transponders centers in order to reach uncovered areas until then.

By April 1984 Parliamentary elections, some important broadcast centers and transponder centers had not yet been installed: Montcaro, which would cover Ribera d'Ebre, Terra Alta, Baix Ebre, and Montsià in the Tarragona province, and the transponders center Pic del O'rri $i$ Vaqueira, which would cover the Pirineos area: Val D’Aran, Pallars Sobirà, Pallars Jussà, and Alt Urgell. Moreover, many other transponder centers were set to cover shadow areas.

To sum up, by April 1984 parliamentary elections, 67\% (635 out of 941) of municipalities and $92 \%$ of population (or $77 \%$, excluding Barcelona) was covered by TV3 (Fig. 1).

\section{Theoretical arguments and hypotheses}

\subsection{Media and voter turnout}

Why could voter turnout be affected by media? If the role of media is, seemingly, providing information, there are at least three distinct theoretical perspectives that could explain this relationship. Firstly, the basic Downs (1957) model states that a voter, in deciding whether or not to vote, calculates the expected utility of either action and votes if the benefits exceed their costs. Part of these costs are related to obtaining information about the candidates and policies (Geys 2006a: 18). Then, it would be expected that the entry of a new media source reduces these costs by making voting less costly. Nevertheless, this rational view is not enough to explain voter turnout since the benefits of voting are very close to zero (in part because the probability of affecting the outcome is almost non-existent).

Secondly, a Downs complementary perspective suggests that the decision to vote does not solely lie on a rational choice, but also individuals can see voting as a 'civic duty' and thus feel morally obliged to do so (Geys 2006a: 19; 2006b: 648). From this

\footnotetext{
3 See "Appendix 2" for pieces of news about the difficulties faced by TV3 to cover the Catalan territory.
} 


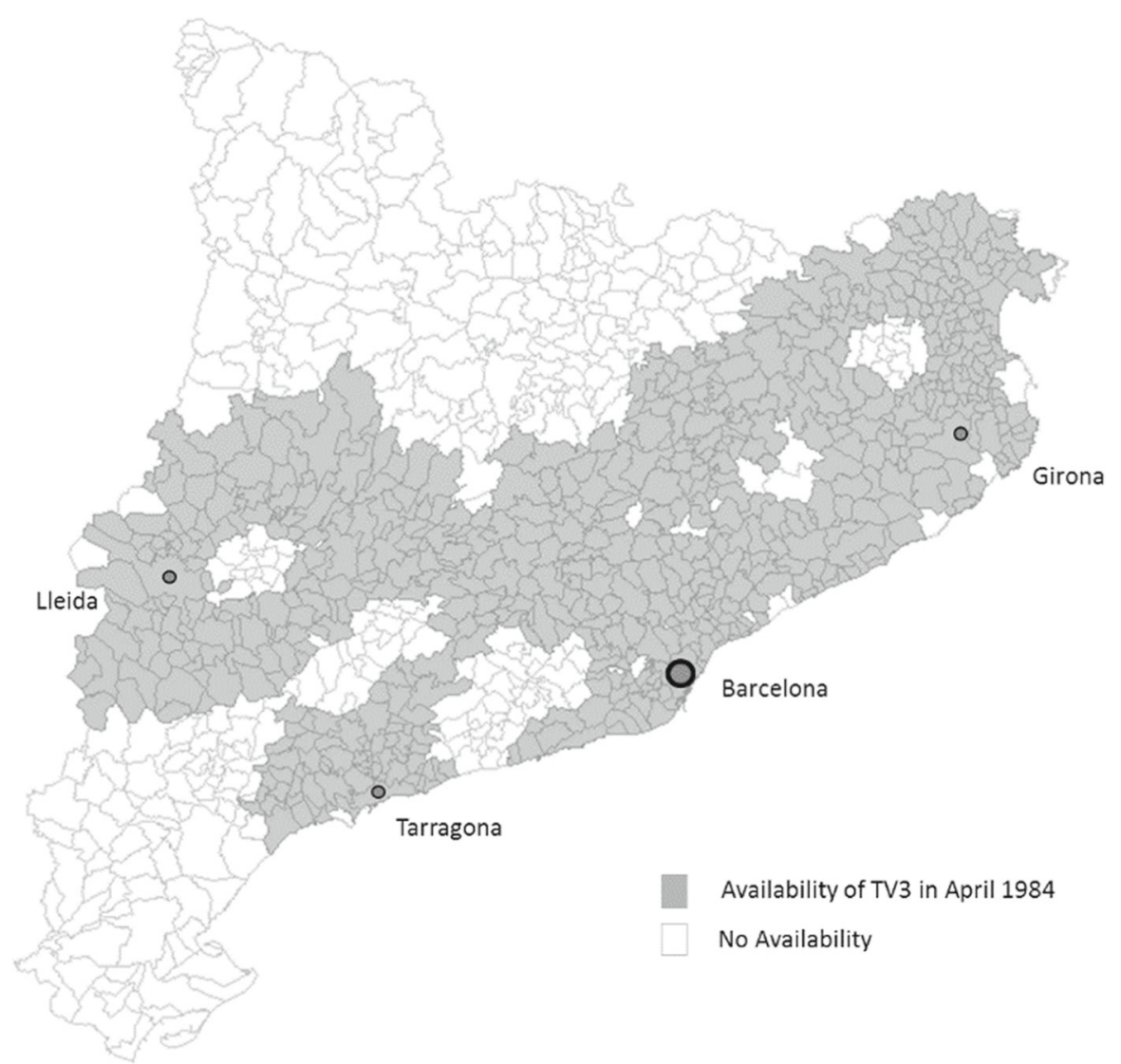

Fig. 1 Availability of TV3 in Catalonia in April 1984. Source: Prepared by the author based on (Montero 1987) and La Vanguardia ("Appendix 2")

perspective, the media, especially when it comes to public media, may enlarge the feeling of civic duty and thus make voting more feasible (Sørensen 2016).

And thirdly, both decision-theoretical (Matsusaka 1995) and game-theoretical models (Feddersen and Pesendorfer 1996, 1997) suggest that better informed individuals are more likely to go out to vote. Matsusaka (1995: 93) argues that 'the value of changing the election outcome is higher when the voter is more confident that she is voting for the right candidate'. Feddersen and Pesendorfer (1996; 1997), employing a game-theoretic model, found that uninformed voters have an incentive to abstain and to delegate their vote to those who are better informed. Nevertheless, as Geys (2006a: 25) points out, the central problem of the these 'information models' is that they cannot explain the mere existence of voter turnout as they assume a predisposition to vote in order to achieve positive turnout levels.

Either way, the empirical evidence brings up a different perspective: the effect depends upon the content of the media, which might lead to either a positive or a negative effect on voter turnout. On the one hand, some empirical studies find a positive 
correlation between voters' information levels and turnout, whether this information is provided by radio (Strömberg 2004), newspapers (Snyder and Strömberg 2010; Gentzkow et al. 2011; Drago et al. 2013; or television (Oberholzer-Gee and Waldfogeland 2010; Sørensen 2016). On the other hand, some contributions point out that an increase in the supply of some media sources may lead to a negative effect on electoral participation due to a crowding-out effect on the existing (and more informative) media (Gentzkow 2006; George and Waldfogel 2008).

The ambiguous effect of media on voter turnout leads us to ask what the effect of TV3 was (if there was any) in Catalonia by the 1984 parliamentary election. As explained in the previous section, given the context in which TV3 emerged, its political implications as well as the good reception of people to the channel, we firstly hypothesize that:

H1 The exposure to TV3 led to an increase in voter turnout in the 1983 Catalan parliamentary election.

\subsection{Media bias and political persuasion}

Theoretically speaking, the existing models of persuasion effects can be divided broadly into two categories (DellaVigna and Kaplan 2008: 81). The first captures rational learning and predicts that exposure to the media may have an impact on beliefs and voting only in the short-run since voters, sooner or later, are able to filter out any bias provided by media. The second channel captures non-rational persuasion and implies that exposure to the media may affect beliefs and voting also in the long-run. Then, understanding the media impact on voting behavior is of interest not only for politics, but also for models of belief updating; and from a policy perspective, if media bias modifies voting behavior, deregulation of media markets might have a large impact on political outcomes.

The general picture emerging from the empirical literature is that media bias indeed has an effect on political views. Some outstanding cases in the literature are the impact of FOX News in the voting for the Republican party in the USA (Albertson and Lawrence 2009; DellaVigna and Kaplan 2007); the impact of public television in Russia (White et al. 2005) and an independent TV channel also in Russia (Enikolopov et al. 2011); the effect of West German television on East Germany attitudes toward authoritarian regimes (Kern and Hainmueller 2009); and the impact of the entry of digital TV on support for Silvio Berlusconi in Italy (Barone et al. 2012). Regarding newspapers, Gerber et al. (2009) also find an effect of The Washington Post (a leftleaning newspaper) and The Washington Times (a right-leaning newspaper) on selfreported voting.

With regards to the case of Catalonia, Hierro (2012: 160) draws on a panel data in order to identify whether TV3 induced changes in national identity from 2004 to 2005; examining whether those who do not tilt toward any nationality in 2004 (i.e. self-identified as both Spanish and Catalan) are more likely to self-identify as either Spanish or Catalan in 2005 as a result of watching TV3. The author does not find any effect of media on national identity. However, it is important to call attention to the identification strategy. Due to the fact that by that time all individuals were exposed 
to TV3 (as the channel was available in the whole of the Catalan territory), there are not a proper counterfactual group to test the impact of the channel, that is, a group of individuals who did not have access to TV3 for exogenous reasons to political preferences.

To sum up, looking into the influence of TV3 in the Catalan political context is a worthwhile research question that can contribute to the literature in the field of political persuasion. However, until now the findings are inconclusive, and therefore this case study needs more scholarly attention. We pose the following second hypothesis:

H2 The exposure to TV3 led to an increase in the CiU vote share in the 1984 Catalan parliamentary election.

\section{Data}

\subsection{Dependent variables}

The main dependent variables are the change in voter turnout and the change in the CiU vote share between the 1980 and 1984 Catalan Parliamentary elections at municipality level. The information comes from the Statistical Institute of Catalonia (Idescat).

Voter turnout is defined in this study as the share of population that cast their vote with respect to the total number of people registered to vote, and the CiU vote share is the number of votes for the $\mathrm{CiU}$ with respect to the total number of votes. Table 1 displays summary statistics. The average voter turnout in municipalities exposed to TV3 went from 57.7 to $69.7 \%$ (a difference of 12 percentage points), while those unexposed to the channel went from 59.2 to $68.1 \%$ (a difference of 8.9 percentage points). That is to say, the change in voter turnout was seemingly larger in municipalities that had TV3 during the 1984 Catalan parliamentary election. On the other hand, the average CiU vote share in municipalities exposed to TV3 went from 34.1 to $64.5 \%$ (a difference of 30.4 percentage points), while in the others went from 33 to $65.3 \%$ (a difference of 32.3 percentage points), that is, the change seems larger in unexposed municipalities.

\subsection{Treatment variable}

The availability of TV3 in April 1984 is, in the jargon of impact evaluation, the treatment variable of this study. Drawing on the information from Montero (1987) and La Vanguardia newspaper presented in the preceding section, we code as 1 whether the municipality was covered by TV3 before April 1984 (the date of the 1984 Catalan parliamentary election), and 0 otherwise (see "Appendix 2" for more detail about the methodology). There are 633 municipalities in the treatment group, and 305 in the control group. Furthermore, in order to test a treatment duration effect, we code the treatment variable as 1 if the municipality was exposed to TV 3 between 4 and 8 months, and 0 if less than 4 months. 


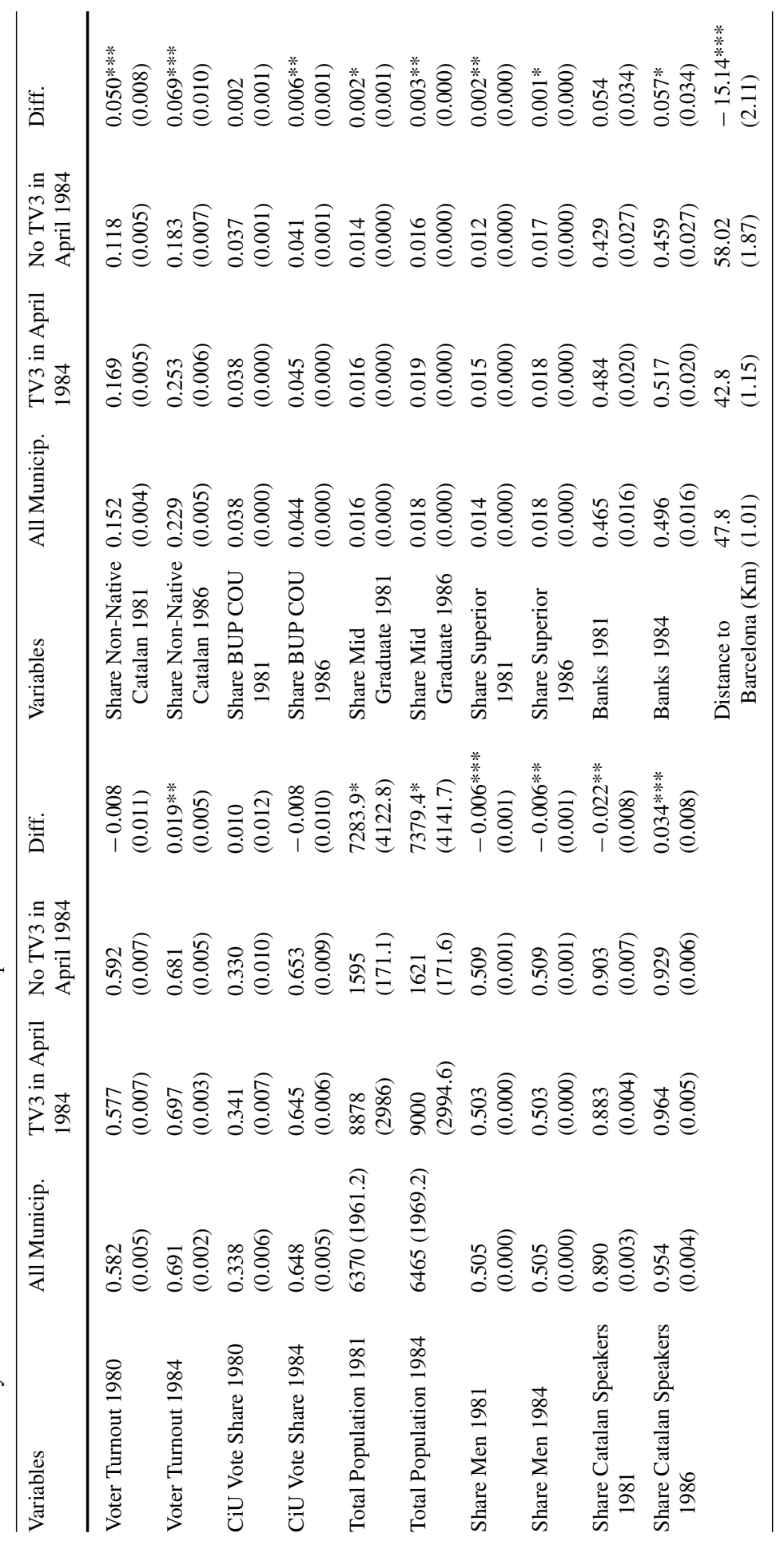




\subsection{Controls}

Table 1 presents summary statistics of time-variant control variables. The group of municipalities exposed to TV3 has on average 8878 inhabitants in 1981, while the unexposed has an average of 1595 . The share of men is similar in the two groups, around $50 \%$, and this proportion is maintained over time. Around $88 \%$ of the population understood Catalan in the treatment group in 1981, while the ratio is 2 percentage points larger in the control group. In 1984, the share of population understanding Catalan increased more in the treatment group, reaching $96.4 \%$, while control group had $92.9 \%$. Furthermore, there were more non-native Catalans in the treatment group than in the control, $16.9 \%$ in 1981 and $25.3 \%$ in 1986. Regarding education, the three indicators (i.e. the share of people that got BUP-COU with respect to total population in 1981 and 1986; the share of people that got a medium level degree with respect to total population in 1981 and 1986; and share of people that had a professional diploma with respect to the total population in 1981 and 1986) are greater in the treatment group with about 2 percentage points. We also include a dummy indicating the presence of financial institutions (banks or saving banks). $48.4 \%$ of municipalities exposed to TV3 had financial institutions in 1981, while $42.3 \%$ in the control groups had these kinds of institutions. The share increases about 3 percentage points in both treatment and control groups in 1984. Finally, control municipalities are further to Barcelona - the capital city of Catalonia - than treatment units. The distance of treatment municipalities to Barcelona is on average $42.8 \mathrm{~km}$, while control units are $58.02 \mathrm{~km}$ to the capital. ${ }^{4}$

The inclusion of population size is suggested by the probability of casting the decisive vote in the election (i.e. making or breaking a tie). The ratio of men is included to control for possible differences in political participation related to sex. The percentage of non-native people and Catalan speakers can also have an effect on electoral outcomes due to differences in political views related to individuals' origin. Educational variables can also influence the electoral participation in the as more sophisticated individuals are more likely to turnout. The dummy indicating the presence of financial institutions (banks or saving banks) in the municipalities is a dummy intended to capture how modern the municipality is economically. Finally, the distance of municipalities to Barcelona might also have some influence in shaping political views due to a geographical spillover effect, where Barcelona's majoritarian political view could affect neighboring areas.

\section{Empirical strategy}

We consider the impact of the TV3 entry on two political outcomes related to electoral results of the Catalan parliamentary elections: the change in voter turnout and the change in the CiU vote share between 1980 and 1984 at the municipality level. To do so, we resort to a natural experiment based on the staggered expansion of

\footnotetext{
${ }^{4}$ Figures of longitude and latitude to estimate the distance of each municipality of Catalonia to Barcelona were taken from Idescat.
} 
TV3 in Catalonia. This strategy exploits the timing of the entry described in Sect. 2. The key identifying assumption is that the TV3 exposure is plausibly exogenous to political attitudes because the delay in the channel entry was mainly caused by technical and logistical issues. However, we still have to take into account some of the municipalities' initial conditions that plausibly determined the order of assignation to TV3.

As a first approach to the effect of the exposure to TV3 on the two political outcomes of interest, we plot the evolution of voter turnout and the CiU's vote share in the Catalan parliamentary elections of 1980, 1984, 1988, and 1992 for two groups of municipalities: exposed and unexposed to TV3 in April 1984 (the date of the Catalan parliamentary election, which is expected to show some impact of the exposure to the channel) (Fig. 2). Figure 2a shows that the change in voter turnout between 1980 and 1984 was larger in municipalities exposed to TV3, where it increased by 12 percentage points (from 57 to $69 \%$ ), while in municipalities not exposed to TV3, it increased by only 8 percentage points (from 59 to $68 \%$ ). Instead, Fig. 2 b shows that this is not the case for the CiU vote share. It increased from 34 to $64 \%$ in municipalities with TV3, and from 33 to $65 \%$ in municipalities without TV3, which represents an increase of 30 and 32 percentage points respectively. That is, $\mathrm{CiU}$ vote share exhibits a smaller change in comparison to the change in voter turnout.

Additionally, Fig. 2c, d display the evolution of voter turnout and CiU's vote share, respectively, in the National congress elections of 1977, 1979, 1982, 1986, and 1989 for the same two groups of municipalities. It is worth noting that TV3 appeared in 1983, and most of Catalonia was already covered by TV3 in 1986 . Thus, it is not possible to claim that the tendency described in these graphs, specifically from 1982 to 1986 , actually captures some TV3 effect.

\subsection{Main specification}

In terms of a regression framework, we estimate a standard two-periods Differencein-Differences (DiD) model using the following first-difference equation.

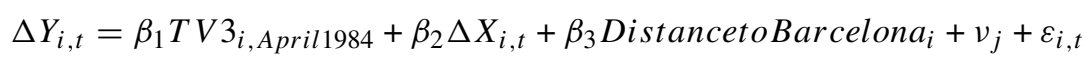

where $\Delta Y_{i, t}$ is the change between 1980 and 1984 in the political outcomes of interest (voter turnout and $\mathrm{CiU}$ vote share) for municipality $i . T V 3_{i, \text { April } 1984}$ is the availability of TV3 in the municipality $i$ in April 1984, thus the coefficient $\beta_{1}$ measures the DiD estimator. $\Delta X_{i, t}$ is the change for time-variant control variables. DistancetoBarcelona $_{i}$. is the time-invariant distance of each municipality to the Capital of Catalonia, Barcelona. In some specifications we also include district fixed effects $v_{j}$ to control for potential time-variant unobserved shocks that affect all municipalities in the district. ${ }^{5}$ Furthermore, in some specifications, observations are weighed by the potential number of voters in the municipality measured by the voting age pop-

\footnotetext{
5 In the context of this research, district means "Comarca", the second smallest geographical unit in Catalonia and Spain after municipalities.
} 


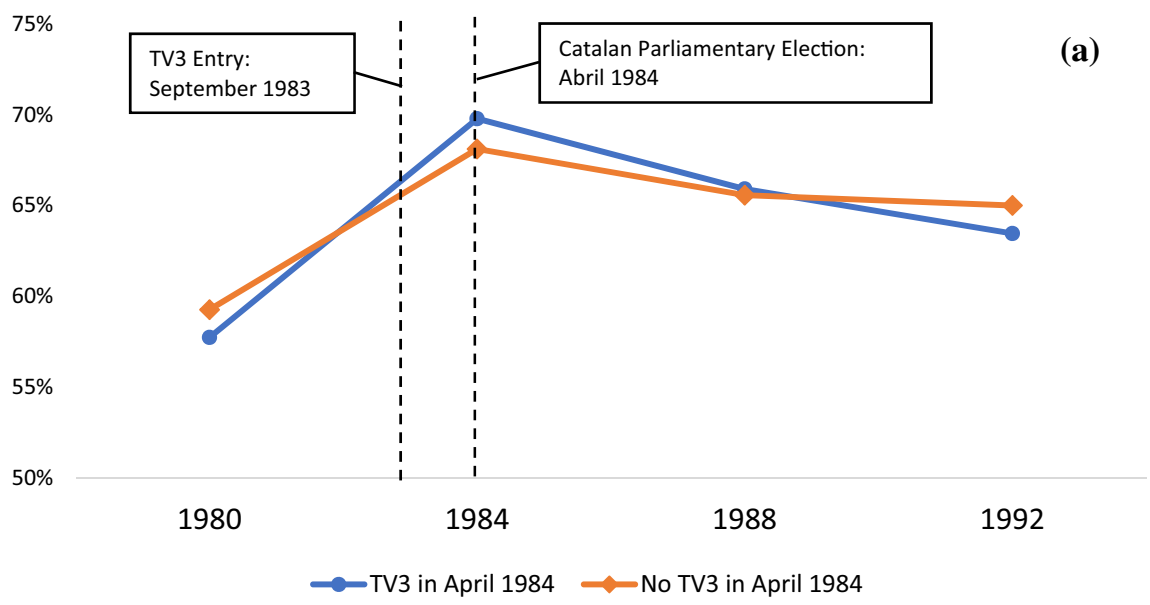

Fuente: Idescat

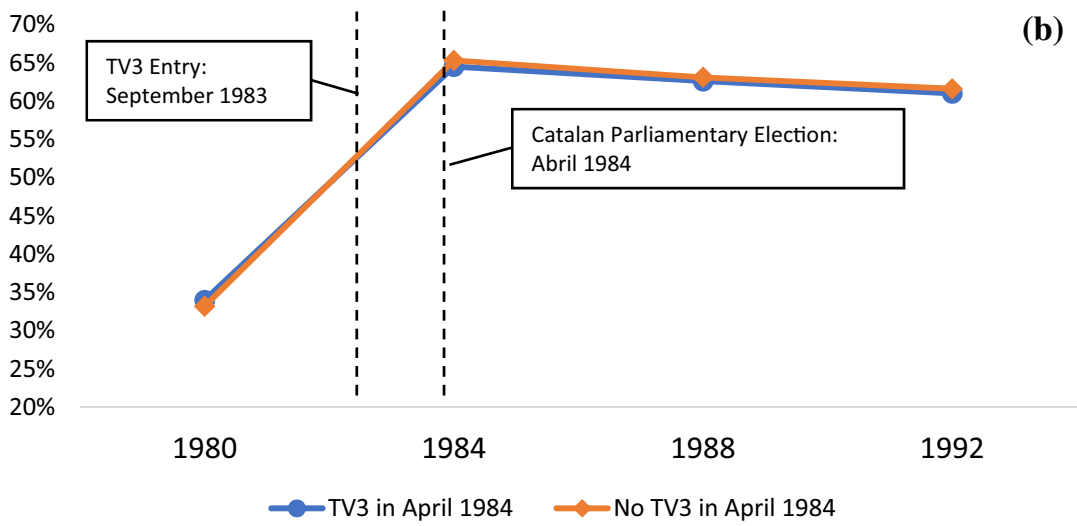

Fuente: Idescat

Fig. 2 Evolution of voter turnout and CiU vote share. a Voter Turnout in Catalan parliamentary elections, b CiU Vote Share in Catalan parliamentary elections, $\mathbf{c}$ Voter Turnout in National Congress (Congreso de los Diputados) Elections and d CiU Vote Share in National Congress (Congreso de los Diputados) Elections

ulation in $1984 .{ }^{6}$ Finally, $\varepsilon_{i, t}$ is the disturbance term. We cluster standard errors at the district level $j$ as there might be important within-cluster correlation.

A potential threat to the validity of the empirical strategy might be caused by the introduction, over the same period of time, of other media such as radio or newspapers that may have affected municipalities differentially in the treatment and control groups. Nevertheless, scarce information does not allow us yet to control for the coverage of other types of media at the municipality level. Regarding radio, however, the concern can be minimized given the higher audience numbers of TV3 in comparison to Catalunya Ràdio. According to Jones (2007: 521), the audience of Catalunya Ràdio

\footnotetext{
6 Results do not change significantly when using other measures such as total population or voter turnout.
} 


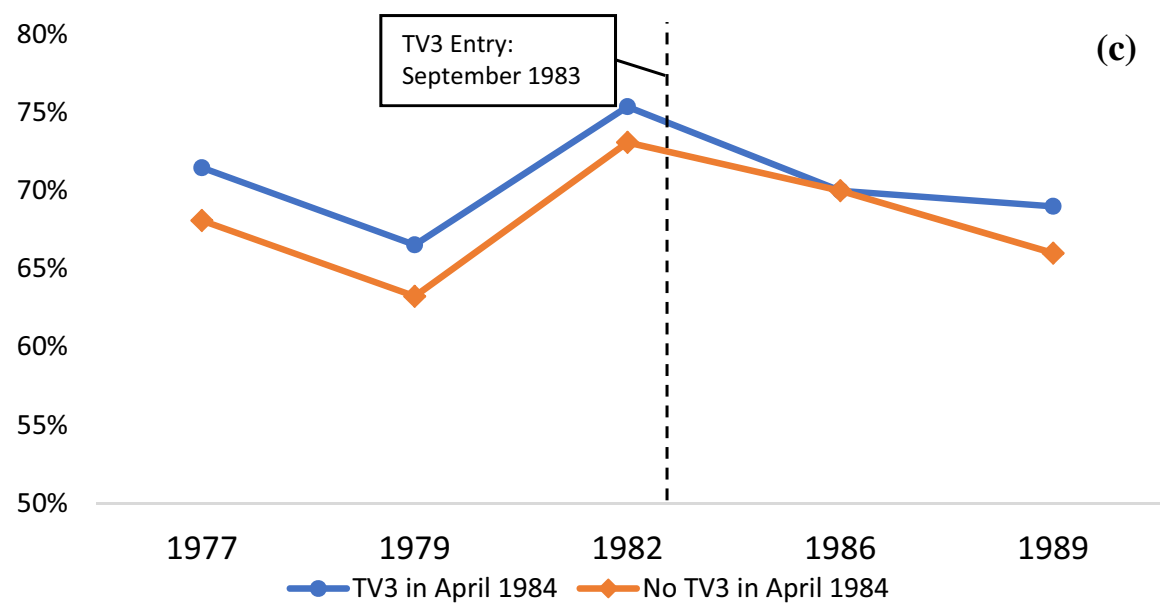

Fuente: Idescat

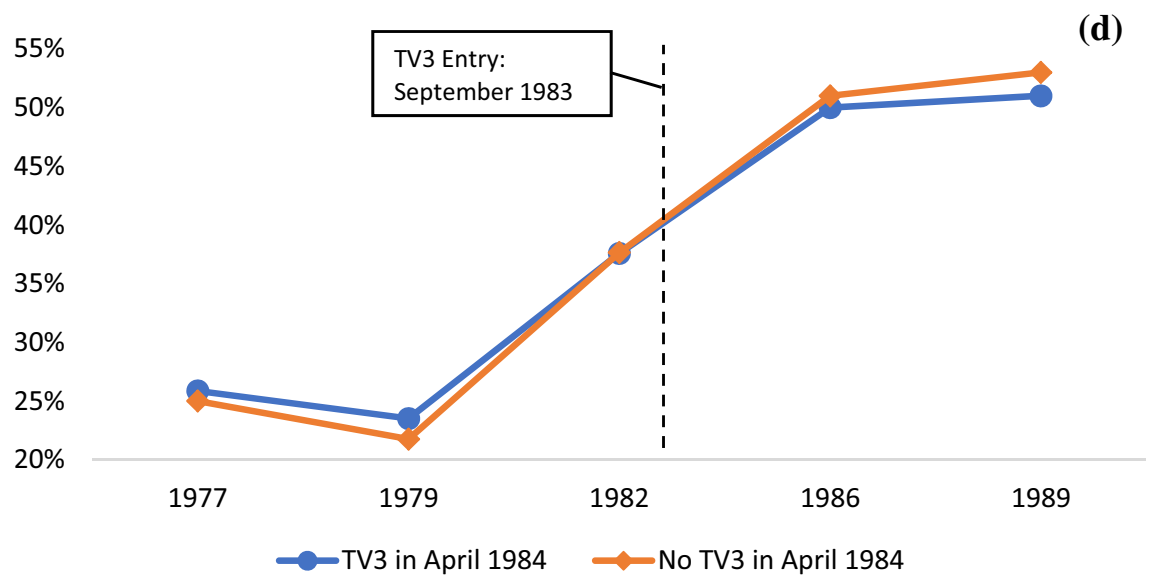

Fuente: Idescat

Fig. 2 continued

reached out 249,000 individuals in 1986 (4\% of the total population of Catalonia), whereas TV3 was about 2,047,000 (34\% of the total population), that is almost nine times larger than the radio audience. With respect to newspapers, unfortunately information on subscribers at the municipality level is not available. These differences could affect the political outcomes so that the results of the effect of TV3 might be biased, future research therefore should be focused on looking into the effect of newspapers on the election. 


\subsection{Robustness check: DiD and PSM}

To address concerns about the municipalities' initial conditions in the assignation to TV3, the estimated probability of participation (or propensity score) can be used to match treatment and control municipalities in the base (pre-program) year (i.e. 1980), and the treatment impact is calculated across participant and matched control units within the common support (Khandker et al. 2010: 80). Then, in order to obtain the propensity scores needed to define the common support and match municipalities, we first implement a Logit model of the availability of TV3 as follows:

$$
T V 3_{i, \text { April1984 }}=\beta_{0}+\beta_{1} X_{i, t}+\beta_{2} \text { Distance to Barcelona }{ }_{i}+\varepsilon_{i, t}
$$

where the dependent variable $T V 3_{i}$, April1984 is a dummy variable indicating the availability of TV3 in municipality $i$ by April 1983. $X_{i, t}$ is a set of initial conditions (some for 1980 and others for 1981 given the availability of information) that might affect the TV3 placement as well as the subsequent trajectories of municipalities' political outcomes. For $X_{i, 1980}$, these are: (i) voter turnout in 1980, (ii) CiU vote share in $1980,^{7}$ and for $X_{i, 1981}$, (iii) $\log$ of total population in 1981, (iv) Share of men with respect to total population in 1981 , (v) Share of non-Catalan people with respect to total population in 1981, (vi) Share of people who speak Catalan with respect to total population in 1981, (vii) Share of people that get BUP-COU with respect to total population in 1981, (viii) Share of people that got a medium level degree with respect to total population in 1981, (ix) Share of people that have a professional diploma with respect to total population in 1981, and (x) Financial institutions in 1981. Distance to Barcelona is the distance of each municipality to Barcelona. The standard errors are clustered at district level and observations are weighted by voting age population in 1984.

\section{Results}

\subsection{Effect of TV3 on voter turnout and the CiU vote share}

Table 2 displays the main econometric results. With respect to our first hypothesis, we find that municipalities exposed to TV3 present a larger change in voter turnout between 1980 and 1984 (Columns 1-4 at Table 2). Availability of TV3 in April 1984 is statistically significant in most of the econometric specifications. We first run a simple DiD regression, that is the Eq. 1 without controls and no weights, and we find that the impact is about 3.1 percentage points (Column 1). In column 2, when we add additional control variables the effect is still positive but it is not significantly different from zero. The regressions in columns 1 and 2 give the same weight to each municipality. In column 3 , in order to give the same weight to each voter, we report results from a regression where we weigh each observation by the voting age population of the municipality. When doing so, the effect of Availability of TV 3 in

\footnotetext{
7 The inclusion of both the previous voter turnout and the CiU vote share is justified as voting may be habit-forming, namely individuals who voted in the past are more likely to vote again in future elections and for similar political agendas (Geys 2006b: 646).
} 
April 1984 on voter turnout is about 8.4 percentage points. Also, when including fixed effects at district level, the effect of TV3 is 6.8 percentage points. ${ }^{8}$

Then, it can be said that the effect of TV3 on voter turnout is statistically significant and it varies from 6.8 to 8.4 percentage points once controlling for a set of variables. The magnitude of these impacts will be analyzed in Sect. 6.4 through the estimation of persuasion rates, as suggested by DellaVigna and Gentzkow (2010).

On the other hand, regarding the second hypothesis, we did not find evidence that TV3 favored the increase in the CiU vote share in those municipalities exposed to the channel. None of the econometric specifications is statistically significant (Columns 6-9 at Table 2). At the same time, let us note that the results are not sufficiently precise to reject relatively large positive or negative impacts. For instance, in our preferred specification the $95 \%$ confidence interval lies approximately between 0.092 p.p. and -0.050 p.p. (Table 2, column 9).

Finally, as a robustness check, Column 5 and 10 in Table 2 display the results of estimating the Eq. 1 within the common support after doing a propensity score matching. The details of this estimation, the balancing test of control variables and the list of municipalities included in the common support are presented in "Appendix 3". 53 treated municipalities are off the common support, while no control municipality is off. Consequently, this specification uses 576 treated municipalities and 305 untreated, for a total of 881. Results do not greatly change: the effect of TV3 on the change in voter turnout between 1980 and 1984 is about 6.2 percentage points (Column 5 in Table 2). On the other hand, there is no impact of TV3 on the CiU vote share (Column 10 in Table 2).

\subsection{Additional results}

\subsubsection{Effect on other political parties}

Although the exposure to TV3 did not impact the CiU vote share, one could still infer that the channel could have either favored or discouraged voting for other political parties competing in the same election. Table 3 displays the estimated coefficients for PSC (Partido de los Socialistas de Cataluña), $\mathrm{PP}^{9}$ (Partido Popular) and PSUC (Partit Socialista Unificat de Catalunya). We present two econometric specifications for each party, one without weights and the other one weighting municipalities by voting age population in 1984. We did not find any significant impact of TV3 on the PP vote share (Columns 3 and 4). However, the results are not conclusive regarding PSC and PSUC. Columns 1 and 2 for PSC and columns 5 and 6 for PSUC show that the effect of the TV3 exposure is positive and significant when weighing observations. For PSC, the effect on the change in its vote share is about 4.3 percentage points, and for PSUC

\footnotetext{
8 Based on "Appendix 2", there are only 10 districts that have both treated and control municipalities. These are: Alt Empordà, Bages, Baix Camp, Baix Empordà, Maresme, Noguera, Osona, Segrià, Selva, and Vallès Oriental. Thus, estimations including district fixed effects are only based on these districts. This also entails using cluster bootstrap standard errors at district level.

9 Idescat labels as "PP" the information about votes for right-wing parties, however it is worth mentioning that this label refers to votes for different right-wing political parties. For instance, the 1980 figure is for Solidaritat Catalana, party that was dissolved after this election.
} 


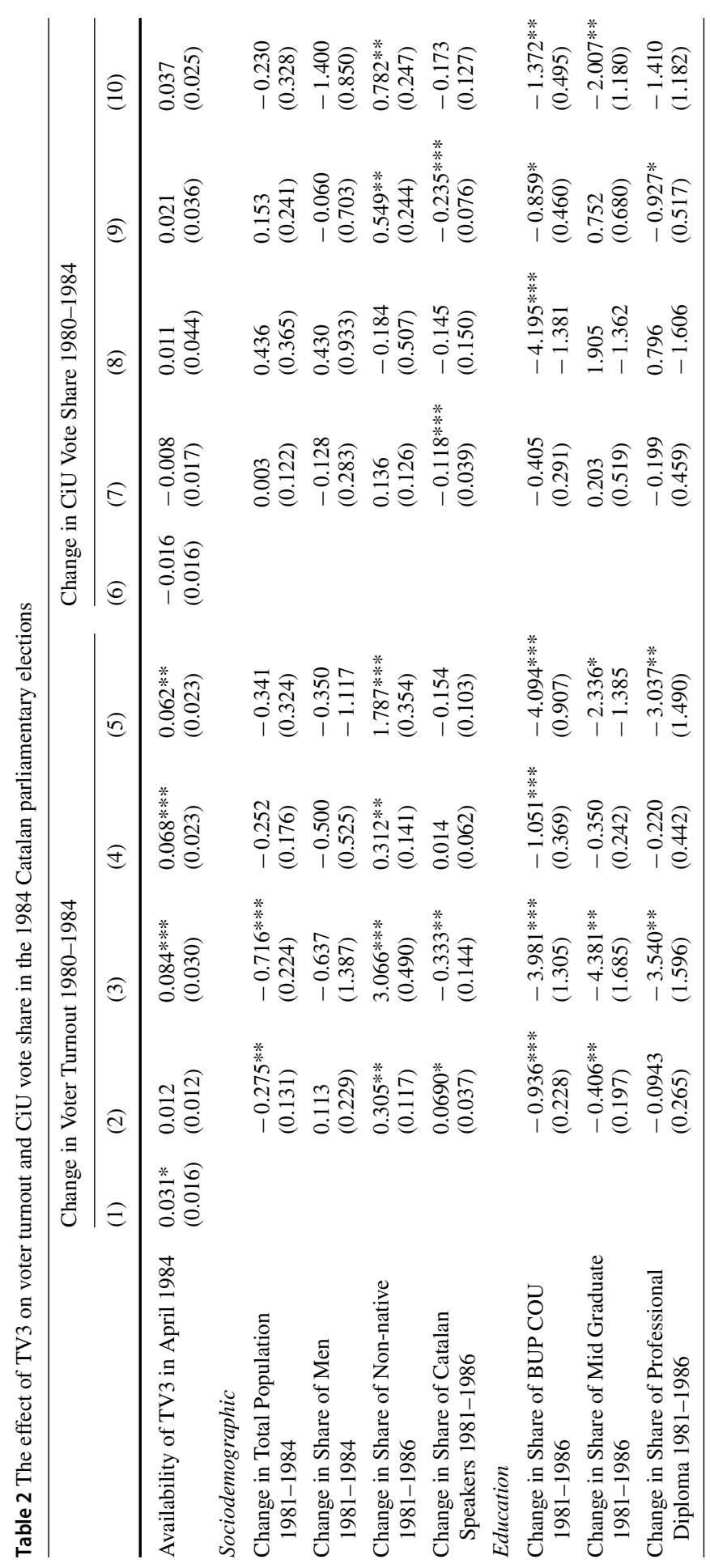




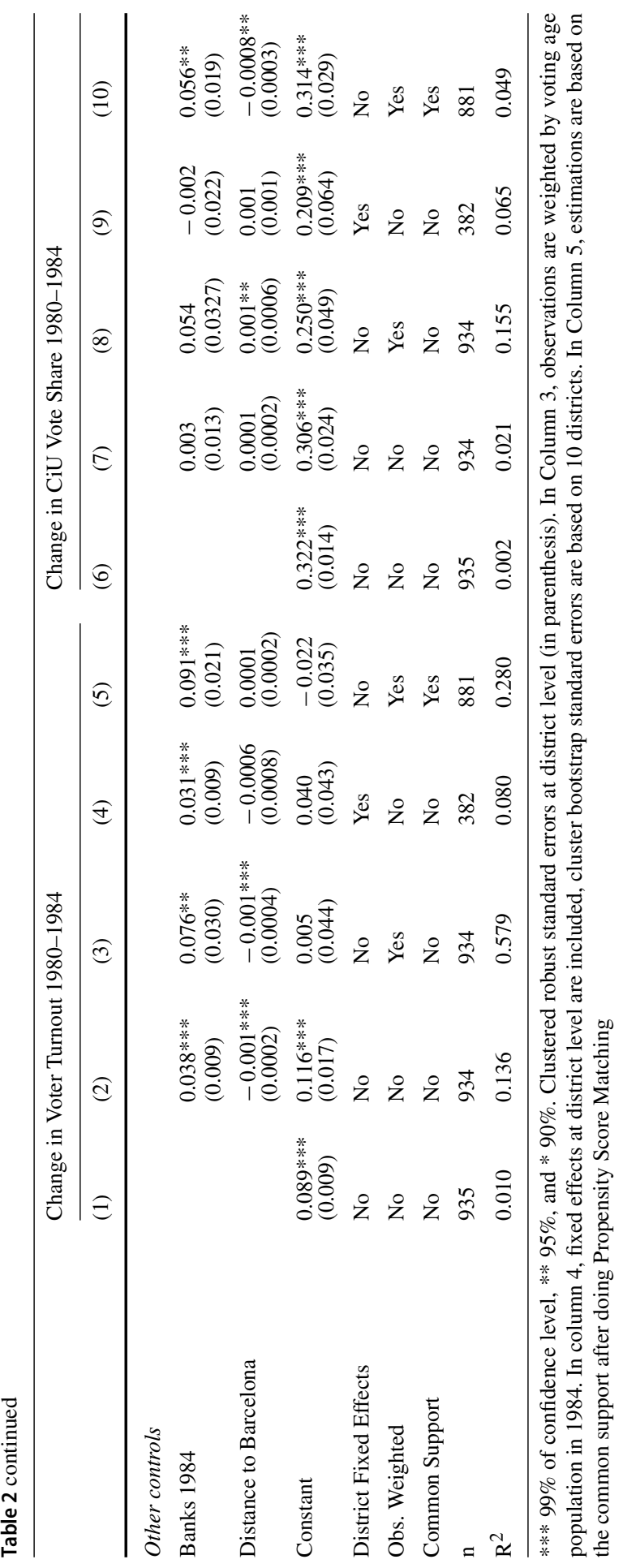


Table 3 Effect on the change in vote share in the 1980-1984 Catalan parliamentary elections of other political parties (PSC, PP and PSUC)

\begin{tabular}{|c|c|c|c|c|c|c|}
\hline & \multicolumn{2}{|l|}{ PSC } & \multicolumn{2}{|l|}{ PP } & \multicolumn{2}{|l|}{ PSUC } \\
\hline & (1) & (2) & (3) & (4) & $(5)$ & (6) \\
\hline $\begin{array}{l}\text { Availability of TV3 in } \\
\text { April } 1984\end{array}$ & $\begin{array}{c}0.013 \\
(0.012)\end{array}$ & $\begin{array}{l}0.043^{*} \\
(0.022)\end{array}$ & $\begin{array}{r}-0.008 \\
(0.006)\end{array}$ & $\begin{array}{r}-0.031 \\
(0.023)\end{array}$ & $\begin{array}{c}0.002 \\
(0.006)\end{array}$ & $\begin{array}{l}0.028^{*} \\
(0.014)\end{array}$ \\
\hline \multicolumn{7}{|l|}{ Sociodemographic } \\
\hline $\begin{array}{l}\text { Change in Total } \\
\text { Population 1981-1984 }\end{array}$ & $\begin{array}{r}-0.222 \\
(0.162)\end{array}$ & $\begin{array}{c}-1.633 * * * \\
(0.571)\end{array}$ & $\begin{array}{c}0.026 \\
(0.042)\end{array}$ & $\begin{array}{c}0.169 \\
(0.213)\end{array}$ & $\begin{array}{r}-0.061 \\
(0.055)\end{array}$ & $\begin{array}{c}-0.888 * * * \\
(0.277)\end{array}$ \\
\hline $\begin{array}{l}\text { Change in Share of Men } \\
\text { 1981-1984 }\end{array}$ & $\begin{array}{r}-0.078 \\
(0.245)\end{array}$ & $\begin{array}{r}-5.131 \\
(3.384)\end{array}$ & $\begin{array}{c}0.086 \\
(0.172)\end{array}$ & $\begin{array}{c}0.348 \\
(0.657)\end{array}$ & $\begin{array}{r}-0.018 \\
(0.109)\end{array}$ & $\begin{array}{l}-2.264 \\
-1.705\end{array}$ \\
\hline $\begin{array}{l}\text { Change in Share of } \\
\text { Non-native 1981-1986 }\end{array}$ & $\begin{array}{l}0.425^{* * * *} \\
(0.104)\end{array}$ & $\begin{array}{l}0.815^{*} \\
(0.439)\end{array}$ & $\begin{array}{r}-0.102 \\
(0.076)\end{array}$ & $\begin{array}{c}0.101 \\
(0.341)\end{array}$ & $\begin{array}{c}-0.205 * * * \\
(0.073)\end{array}$ & $\begin{array}{c}0.077 \\
(0.293)\end{array}$ \\
\hline $\begin{array}{l}\text { Change in Share of } \\
\text { Catalan Speakers } \\
\text { 1981-1986 }\end{array}$ & $\begin{array}{l}0.143 * * \\
(0.061)\end{array}$ & $\begin{array}{l}1.120 * * * \\
(0.378)\end{array}$ & $\begin{array}{c}0.011 \\
(0.023)\end{array}$ & $\begin{array}{r}-0.038 \\
(0.077)\end{array}$ & $\begin{array}{c}0.023 \\
(0.023)\end{array}$ & $\begin{array}{l}0.504 * * * \\
(0.175)\end{array}$ \\
\hline \multicolumn{7}{|l|}{ Education } \\
\hline $\begin{array}{l}\text { Change in Share of BUP } \\
\text { COU 1981-1986 }\end{array}$ & $\begin{array}{c}-0.538 * * \\
(0.234)\end{array}$ & $\begin{array}{c}-7.550 * * * \\
(1.678)\end{array}$ & $\begin{array}{c}0.035 \\
(0.127)\end{array}$ & $\begin{array}{c}1.423 \\
(0.859)\end{array}$ & $\begin{array}{l}0.267 * * \\
(0.107)\end{array}$ & $\begin{array}{c}-3.292 * * * \\
(1.003)\end{array}$ \\
\hline $\begin{array}{c}\text { Change in Share of Mid } \\
\text { Graduate 1981-1986 }\end{array}$ & $\begin{array}{r}-0.659 \\
(0.421)\end{array}$ & $\begin{array}{r}-0.179 \\
(1.570)\end{array}$ & $\begin{array}{c}0.073 \\
(0.111)\end{array}$ & $\begin{array}{c}-1.249 * * \\
(0.607)\end{array}$ & $\begin{array}{r}-0.092 \\
(0.095)\end{array}$ & $\begin{array}{c}0.360 \\
(0.939)\end{array}$ \\
\hline $\begin{array}{l}\text { Change in Share of } \\
\text { Professional Diploma } \\
\text { 1981-1986 }\end{array}$ & $\begin{array}{c}-0.721 * * \\
(0.310)\end{array}$ & $\begin{array}{r}-1.989 \\
(1.657)\end{array}$ & $\begin{array}{l}0.428 * * \\
(0.186)\end{array}$ & $\begin{array}{r}-1.785 \\
(1.299)\end{array}$ & $\begin{array}{l}0.225 \\
(0.179)\end{array}$ & $\begin{array}{c}1.091 \\
(1.338)\end{array}$ \\
\hline \multicolumn{7}{|l|}{ Other controls } \\
\hline Banks 1984 & $\begin{array}{l}0.025 * \\
(0.012)\end{array}$ & $\begin{array}{c}0.020 \\
(0.024)\end{array}$ & $\begin{array}{c}0.003 \\
(0.005)\end{array}$ & $\begin{array}{r}-0.018 \\
(0.012)\end{array}$ & $\begin{array}{c}-0.017 * * * \\
(0.004)\end{array}$ & $\begin{array}{c}-0.031 * * \\
(0.013)\end{array}$ \\
\hline Distance to Barcelona & $\begin{array}{r}-0.0001 \\
(0.0002)\end{array}$ & $\begin{array}{c}0.0006 \\
(0.0003)\end{array}$ & $\begin{array}{l}0.0008 * * * \\
(0.0001)\end{array}$ & $\begin{array}{c}0.0001 \\
(0.0004)\end{array}$ & $\begin{array}{c}-0.0003 * * \\
(0.0001)\end{array}$ & $\begin{array}{c}0.0003 \\
(0.0002)\end{array}$ \\
\hline Constant & $\begin{array}{r}-0.022 \\
(0.016)\end{array}$ & $\begin{array}{c}-0.077 * * \\
(0.033)\end{array}$ & $\begin{array}{c}0.010 \\
(0.008)\end{array}$ & $\begin{array}{c}0.054 \\
(0.041)\end{array}$ & $\begin{array}{r}-0.021 * \\
(0.011)\end{array}$ & $\begin{array}{c}-0.083 * * * \\
(0.030)\end{array}$ \\
\hline Obs. Weighted & No & Yes & No & Yes & No & Yes \\
\hline $\mathrm{n}$ & 934 & 934 & 934 & 934 & 934 & 934 \\
\hline $\mathrm{R}^{2}$ & 0.122 & 0.522 & 0.199 & 0.050 & 0.061 & 0.303 \\
\hline
\end{tabular}

$* * * 99 \%$ of confidence level, $* * 95 \%$, and * $90 \%$. Clustered robust standard errors at district level (in parenthesis). Observations in Columns 2, 4 and 6 are weighted by voting age population in 1984

is about 2.8 percentage points. Exploring and explaining with more detail a possible effect of TV3 on other political parties in this election is a relevant research path.

\subsubsection{Treatment duration effect}

Eight months passed since TV3 began the transmissions until the Catalan parliament elections in April 1984, but not all treated municipalities were assigned to TV3 at the 


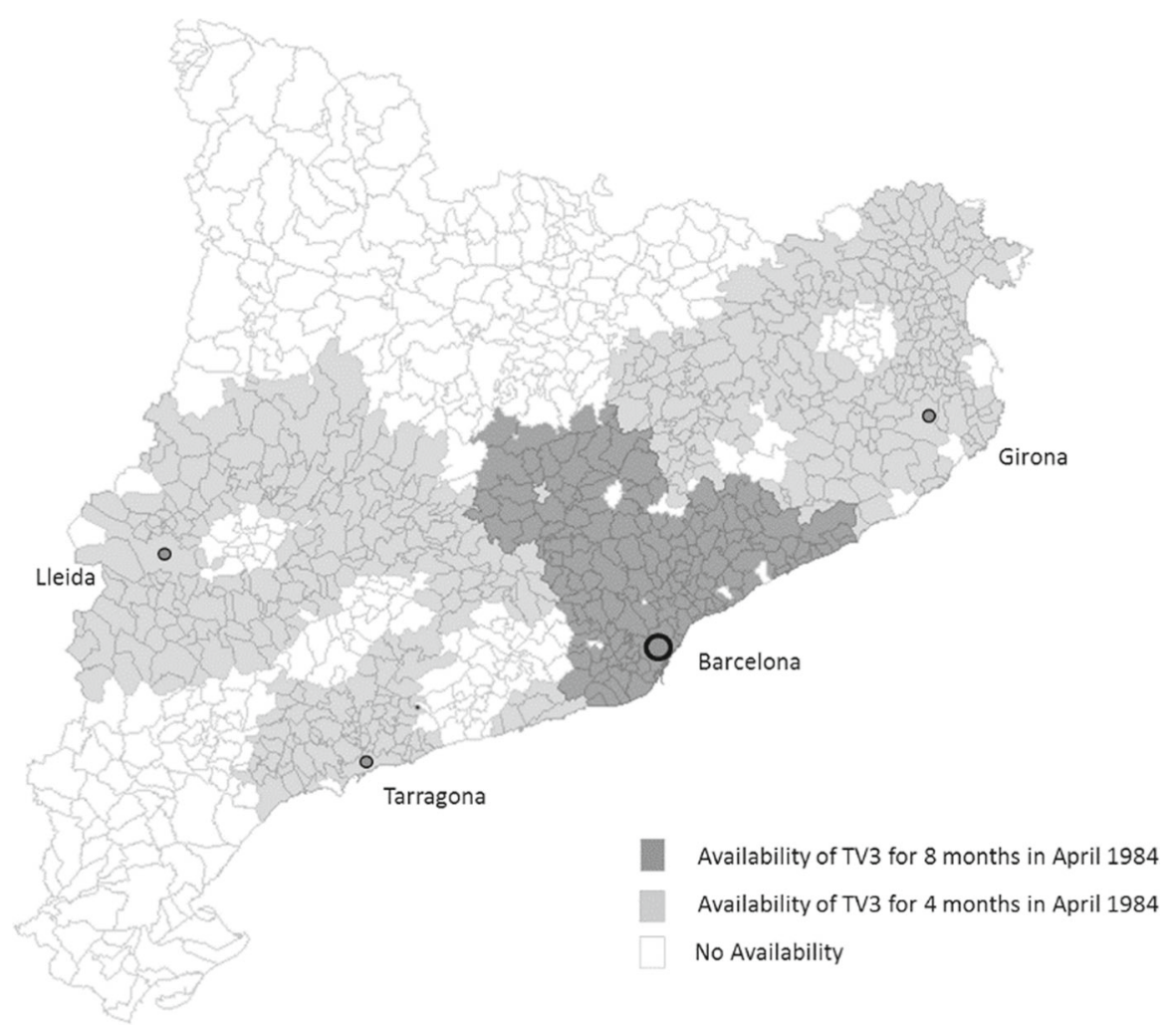

Fig. 3 Availability of TV3 by duration in Catalonia in April 1984

same time. In order to check whether there is a treatment duration effect, we split the treatment group in two: those who received TV 3 for a period between 4 and 8 months and those who received it for less than 4 months (Fig. 3).

When reducing the sample to those municipalities exposed to TV3 in April 1984, we have 235 municipalities treated between 4 and 8 months, and 378 municipalities treated for less than 4 months. As in preceding models, we run different econometric specifications (without controls, with controls, weighting observations by voting age population and combining DiD with PSM). We find that there was not effect of TV3 on voter turnout or the CiU's vote share (Table 4). Thus, we cannot claim that the passage of time intensified the effect of TV3 on the treatment group.

\subsection{Placebo tests}

Placebo tests are necessary to check whether the parallel trend assumption critical in the DD method, is plausible in this study. The first placebo uses a previous electoral process to check whether there are pre-existing trends in the political outcomes of interest. Since the period under analysis (1980-1984) corresponds to the first two parliamentary elections in Catalonia, there are no previous parliamentary elections to 
Table 4 Treatment duration effect

\begin{tabular}{|c|c|c|c|c|}
\hline & \multicolumn{2}{|l|}{ Voter turnout } & \multicolumn{2}{|c|}{ CiU vote share } \\
\hline & (1) & (2) & (3) & (4) \\
\hline Treatment duration $^{\mathrm{a}}$ & $\begin{array}{c}0.022 \\
(0.025)\end{array}$ & $\begin{array}{r}-0.013 \\
(0.045)\end{array}$ & $\begin{array}{c}0.025 \\
(0.027)\end{array}$ & $\begin{array}{c}0.059 \\
(0.096)\end{array}$ \\
\hline \multicolumn{5}{|l|}{ Sociodemographic } \\
\hline $\begin{array}{l}\text { Change in Total Population } \\
\text { 1981-1984 }\end{array}$ & $\begin{array}{c}-0.364 * * \\
(0.163)\end{array}$ & $\begin{array}{c}-0.548^{* *} \\
(0.205)\end{array}$ & $\begin{array}{c}0.102 \\
(0.146)\end{array}$ & $\begin{array}{c}0.439 \\
(0.409)\end{array}$ \\
\hline $\begin{array}{l}\text { Change in Share of Men } \\
\text { 1981-1984 }\end{array}$ & $\begin{array}{r}-0.074 \\
(0.315)\end{array}$ & $\begin{array}{r}-1.235 \\
(1.574)\end{array}$ & $\begin{array}{c}0.131 \\
(0.243)\end{array}$ & $\begin{array}{c}0.128 \\
(0.985)\end{array}$ \\
\hline $\begin{array}{l}\text { Change in Share of Non-native } \\
\text { 1981-1986 }\end{array}$ & $\begin{array}{l}0.370 * * \\
(0.151)\end{array}$ & $\begin{array}{l}3.885 * * * \\
(0.586)\end{array}$ & $\begin{array}{c}0.356^{*} \\
(0.148)\end{array}$ & $\begin{array}{r}-0.488 \\
(0.684)\end{array}$ \\
\hline $\begin{array}{l}\text { Change in Share of Catalan } \\
\text { Speakers 1981-1986 }\end{array}$ & $\begin{array}{c}0.089 * \\
(0.050)\end{array}$ & $\begin{array}{c}-0.446 * * \\
(0.141)\end{array}$ & $\begin{array}{c}-0.195 * * * \\
(0.045)\end{array}$ & $\begin{array}{r}-0.172 \\
(0.161)\end{array}$ \\
\hline \multicolumn{5}{|l|}{ Education } \\
\hline $\begin{array}{l}\text { Change in Share of BUP COU } \\
\text { 1981-1986 }\end{array}$ & $\begin{array}{c}-1.224 * * * \\
(0.296)\end{array}$ & $\begin{array}{c}-5.578 * * * \\
(1.246)\end{array}$ & $\begin{array}{r}-0.799 * \\
(0.392)\end{array}$ & $\begin{array}{c}-4.837 * * \\
(1.488)\end{array}$ \\
\hline $\begin{array}{l}\text { Change in Share of Mid Graduate } \\
\text { 1981-1986 }\end{array}$ & $\begin{array}{r}-0.332 \\
(0.232)\end{array}$ & $\begin{array}{c}-4.831 * * \\
(1.886)\end{array}$ & $\begin{array}{c}0.599 \\
(0.486)\end{array}$ & $\begin{array}{c}1.171 \\
(1.518)\end{array}$ \\
\hline $\begin{array}{l}\text { Change in Share of Professional } \\
\text { Diploma 1981-1986 }\end{array}$ & $\begin{array}{c}0.050 \\
(0.317)\end{array}$ & $\begin{array}{r}-0.996 \\
(1.950)\end{array}$ & $\begin{array}{r}-0.502 \\
(0.386)\end{array}$ & $\begin{array}{c}1.368 \\
(1.744)\end{array}$ \\
\hline \multicolumn{5}{|l|}{ Other controls } \\
\hline Banks 1984 & $\begin{array}{l}0.039 * * \\
(0.010)\end{array}$ & $\begin{array}{c}0.038 \\
(0.030)\end{array}$ & $\begin{array}{r}-0.005 \\
(0.017)\end{array}$ & $\begin{array}{l}0.090 * * \\
(0.040)\end{array}$ \\
\hline Distance to Barcelona & $\begin{array}{c}-0.0008 * * \\
(0.0004)\end{array}$ & $\begin{array}{r}-0.002 * * \\
(0.0007)\end{array}$ & $\begin{array}{c}0.0008 \\
(0.0006)\end{array}$ & $\begin{array}{c}0.002 \\
(0.001)\end{array}$ \\
\hline Constant & $\begin{array}{l}0.107 * * * \\
(0.026)\end{array}$ & $\begin{array}{c}0.053 \\
(0.066)\end{array}$ & $\begin{array}{l}0.251^{* * *} \\
(0.039)\end{array}$ & $\begin{array}{c}0.196 \\
(0.114)\end{array}$ \\
\hline Obs. Weighted & No & Yes & No & Yes \\
\hline $\mathrm{n}$ & 613 & 613 & 613 & 613 \\
\hline $\mathrm{R}^{2}$ & 0.153 & 0.570 & 0.057 & 0.248 \\
\hline
\end{tabular}

Clustered robust standard errors at district level (in parenthesis). Observations in Columns 2 and 4 are weighted by voting age population in 1984

$* * * 99 \%$ of confidence level, $* * 95 \%$, and $* 90 \%$

a Treatment Duration: 1 : between 4 and 8 months, and 0: less than 4 months

test parallel trends. Nevertheless, we draw on the national parliamentary elections of 1977 and 1979 to check pre-existing trends in political outcomes of interest. Columns 1-4 in Table 5 shows that the treatment variable, Availability of TV3 in April 1984, had no impact on voter turnout or CiU vote share in the change in national elections between 1977 and 1979, which suggests that there are no pre-existing trends. 


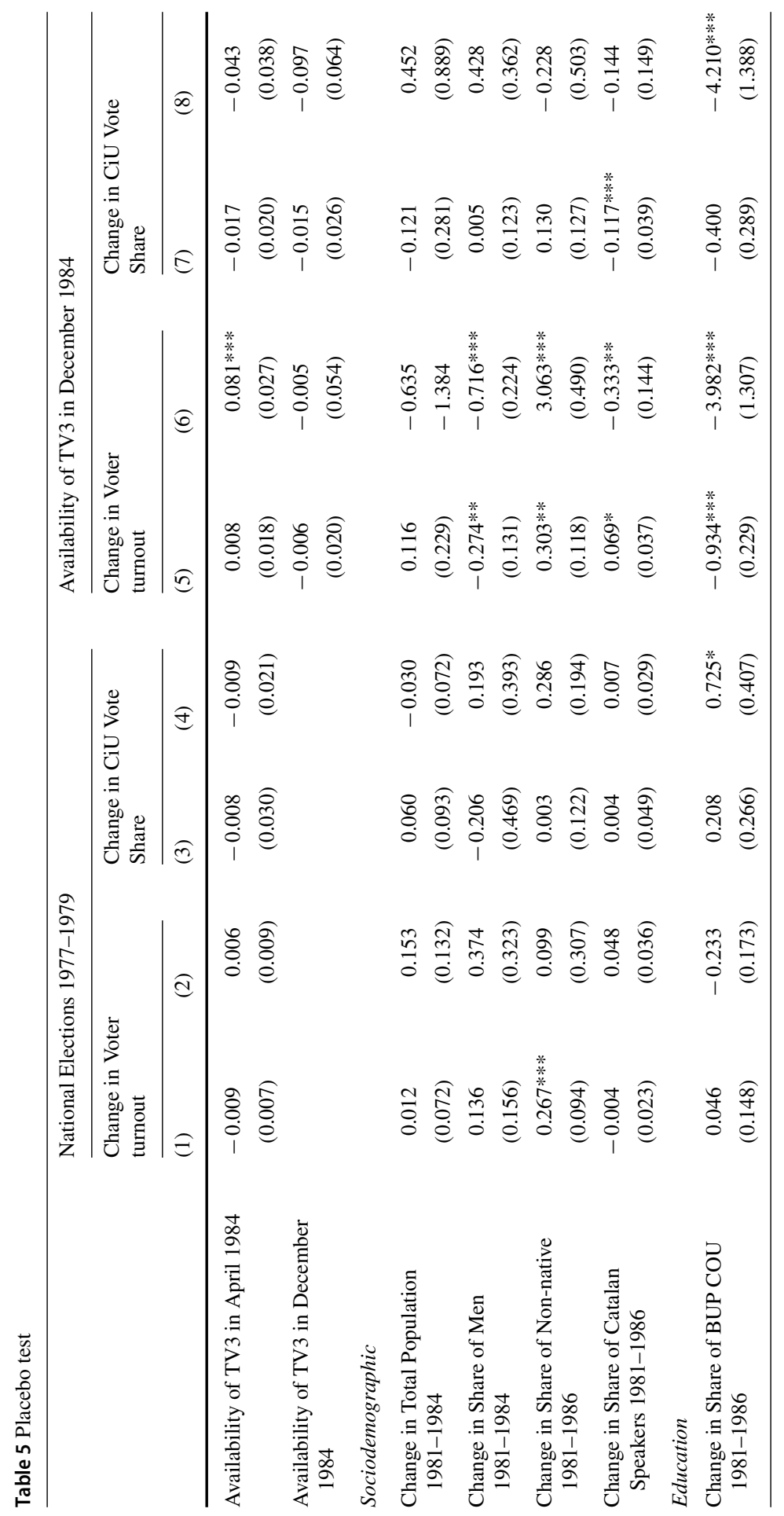




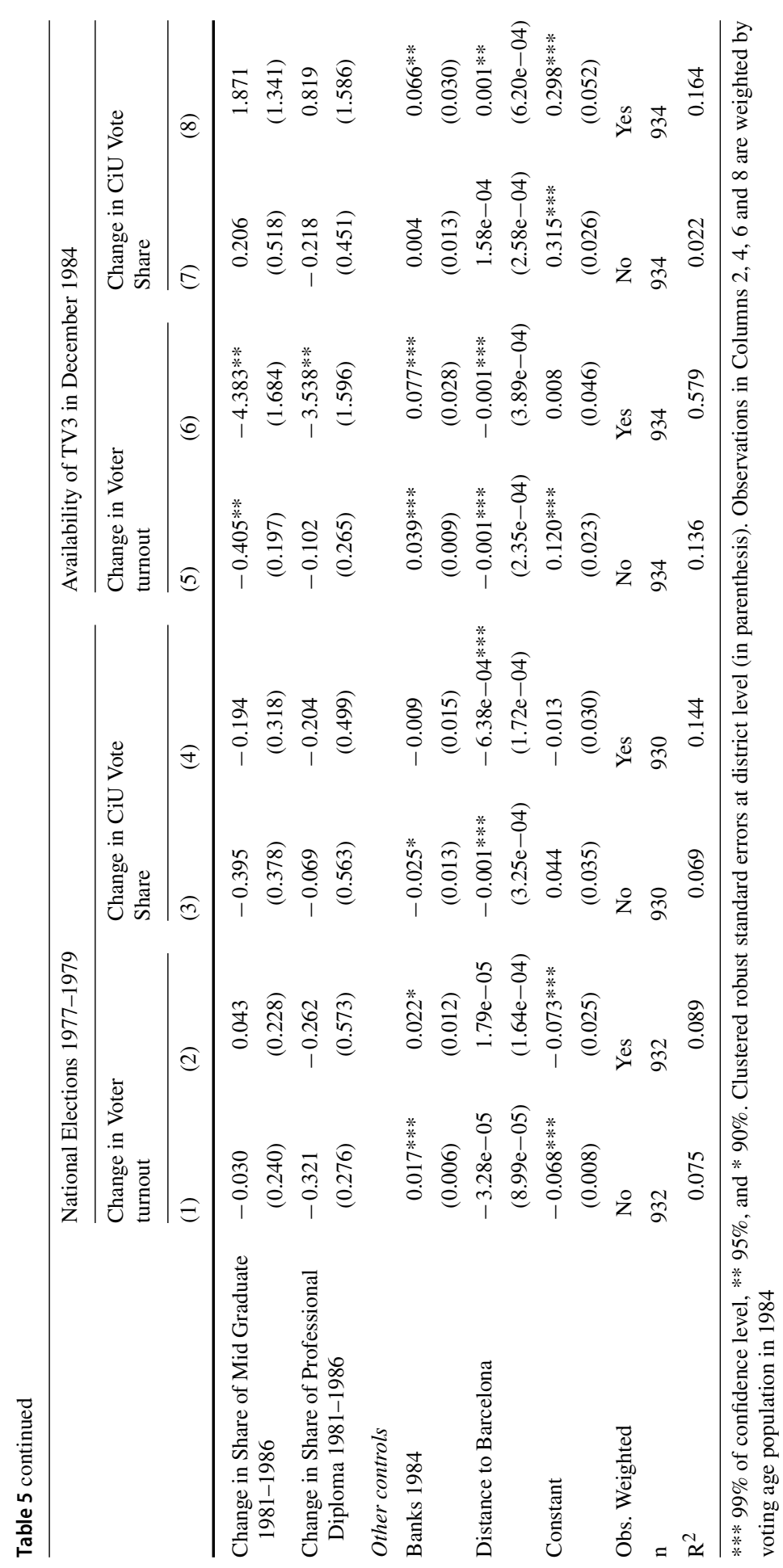


The second placebo treatment is a variable that uses data on the posterior diffusion of TV3 between April 1984 and December 1984 (i.e. twenty months later than the initial treatment variable). In April 1984, 613 municipalities were treated and 323 were untreated, which is indeed the size of our main treatment and control groups. By December 1984, TV3 had reached out to159 municipalities more. Then, we construct this placebo variable as a dummy that takes on 1 for municipalities that were reached by TV3 between April 1984 and December 1984 (i.e. 159 municipalities) and 0 otherwise. If the exposure to TV3 is indeed causing the effect in the outcome, then the placebo should not be significant (otherwise, that would be capturing anticipatory effects or pre-existing trends).

Columns 5-8 in Table 5 show that the placebo, Availability of TV 3 in December 1984, support our findings. For voter turnout, the placebo is not significant (and the actual treatment is significant), which suggests that there are no pre-existing trends. On the other hand, neither the impact of the placebo nor the actual treatment for the $\mathrm{CiU}$ vote share are significant, which supports our findings regarding a lack of political persuasion of TV3 in this setting.

Finally, the third placebo tests whether there is some effect of TV3 within the control group by randomly assigning a fake treatment in this group. There should not be significant differences between the fake treated and untreated, otherwise it would be capturing pre-existing trends. We produce this fake placebo treatment maintaining the same ratio of the total treated and control municipalities, namely $65.64 \%$ of treated. Then, we have got 211 (fake) treated and 110 untreated municipalities within the control group. We repeat this fake random assignation 5.000 times and we calculate how often the impact of these fake treatments is significant. For voter turnout, when specifying the model 1 with no weights, $95 \%$ of times the fake treatment is statistically insignificant, and $86 \%$ when weighting observations by potential number of voters. For CiU vote share, $94 \%$ of times the fake treatment is statistically insignificant for the unweighted model, and $92 \%$ for the weighted model. ${ }^{10}$

\subsection{Persuasion rates}

Persuasion rates are a measure of the percentage of receivers that change the behavior amongst those that receive a message and are not already persuaded (DellaVigna and Gentzkow 2010).

The persuasion rate is defined as follows:

$$
f=100 * \frac{y_{T}-y_{C}}{e_{T}-e_{C}} \frac{1}{\left(1-y_{0}\right)}
$$

where $e_{i}$ is the share of group $i$ receiving the message, $y_{i}$ is the share of group $i$ adopting the behavior of interest, and $y_{0}$ is the share that would adopt if there were no message. Due to that $y_{0}$ is not observed, we can approximate it by $y_{C}$, the turnout in the control

$\overline{10}$ The results of the fake treatment placebo are not reported, but they are available upon request. 
group, as long as the exposure to TV3 of the control groups is zero $\left(e_{C}=0\right)$, which is the case in this study. ${ }^{11}$

The persuasion rate captures the effect of the persuasion treatment on the relevant behavior $\left(y_{T}-y_{C}\right)$, which is the estimated effect of the change in the political outcomes $\hat{\beta}_{1}$, adjusting for exposure to the message $\left(e_{T}-e_{C}\right)$ and for the size of the population left to be convinced $\left(1-y_{0}\right)$.

For the case of voter turnout, the value of $y_{T}-y_{C}$ is 0.07 [i.e. the average effect of TV3 on voter turnout of our preferred specifications in Table 2: 0.084 (Column 3), 0.068 (Column 4) and 0.062 (Column 4)]. Due to the fact that $y_{0} \approx y_{C}$, then $y_{0}=0.68$, which is the turnout in the control group in the 1984 Catalan Parliamentary election. For the exposure rate $\left(e_{T}-e_{C}\right)$, we use two possibilities. First, we take $\left(e_{T}-e_{C}\right)=$ $(34 \%-0)$ if we follow the figures about TV3 audience provided by Jones (2007) for 1986 - assuming that this audience is very similar in 1984-and $e_{C}=0$. Second, we take $\left(e_{T}-e_{C}\right)=(100 \%-0)$ assuming that the channel might affect all eligible voters in Catalonia. Using the Eq. 3, the persuasion rate of TV3 on voter turnout in the 1984 Catalan parliamentary election has an upper-bound of about $64.3 \%$, and a lower-bound of $21.9 \%$. Therefore, it can be said that at least $21.9 \%$ of those who were not already persuaded in the treated population changed their behavior and went out to vote due to the influence of TV3.

Persuasion rates in the literature How large is the persuasion rate? DellaVigna and Gentzkow (2010) provide a summary of the persuasion rates obtained by salient studies in different outcomes of interest. With respect to voter turnout, we have the following figures, which it works as reference points: Gerber and Green (2000), 15.6\%; Green and Gerber (2001), 20.4\%; Green et al. (2003), 11.5\%; Gentzkow (2006), 4.4\%, and Gentzkow and Shapiro (2009), 12.9\%. Then, it can be regarded that, excepting for Green and Gerber (2001), the persuasion rate of TV3 on voter turnout (21.9\% for the lower-bound persuasion rate) in the 1984 Catalan parliamentary election is comparatively larger with respect to other case studies.

\subsection{Mechanisms}

This paper provides evidence about the impact of TV3 on electoral participation in Catalonia in the early eighties. However, it is still necessary to understand the specific mechanisms that enabled the Catalan channel exerting influence on voter turnout. This is so, above all, given the peculiar historical context under analysis: the first two Catalan parliamentary elections after about 40 years of Franquist dictatorship.

In order to explore some mechanisms, we run several regressions interacting the treatment variable, Availability of TV3 in April 1984, with some municipalities' demographic characteristics. In doing so, we expect to find conditional effects

\footnotetext{
11 DellaVigna and Gentzkow (2010: 5) provides a demonstration of such approximation. Assuming random exposure and a constant persuasion rate $f$, the share in group $i$ who adopt the behavior is $y_{i}=y_{0}+$ $e_{i} f\left(1-y_{0}\right)$. Rearranging this expression gives Eq. 3. Solving the system for $y_{0}$, it can be obtained $y_{0}=$ $y_{C}-e_{C}\left(y_{T}-y_{C}\right)\left(e_{T}-e_{C}\right)$. The approximation $y_{0}=y_{C}$ is valid as long as the exposure rate in the control group is small $\left(e_{C} \approx 0\right)$ or the effect of the treatment is small $\left(y_{T}-y_{0} \approx 0\right)$.
} 
of the TV3 impact on voter turnout. Specifically, we interact the treatment with (1) share of men, (2) share of Catalan speakers, and (3) share of population with education (BUP COU, mid graduate and professional diploma). However, we did not find any conclusive conditional effect of the exposure to TV3 on these variables. $^{12}$

Another mechanism might be the type of content that TV3 supplied by that time. Could it be proved that news or programs encouraged people going out to vote, as well as voting for a specific political party? It is important to go into a content analysis to study with more detail the mechanism by which TV3 could influence political outcomes.

\section{Final remarks}

This study contributes to the discussion on the media effect on electoral outcomes in a setting unexplored until now: a case study in which a relevant sub-national television channel with a supposedly partisan and pro-independence bias that might exert influence on the electoral results. The main conclusion arising from this study is that TV3 caused an increment in the voter turnout in the 1984 Catalan parliamentary election, but there is no conclusive evidence that the channel caused a change in the $\mathrm{CiU}$ vote share, political coalition that has been associated to this channel since its foundation.

Regarding voter turnout, unlike some studies like Gentzkow's (2006) who finds a negative impact of television on voter turnout as a result of a crowding-out effect, TV3 seemingly complemented the information provided by traditional media such as the Spanish channel TVE, newspapers, and radio, that influenced individuals to go out to vote in the 1984 Catalan parliamentary election. This finding is interesting but not surprising. Unlike the Gentzkow's (2006) study demonstrating that television as a whole could decrease turnout, a new channel with a great political significance (such as the case of TV3) that provides lots of information to a particular region would instead increase turnout. Additionally, this finding is congruent with other studies focused on other type of media such as radio and newspapers (Strömberg 2004; Oberholzer-Gee and Waldfogeland 2010; Snyder and Strömberg 2010; Gentzkow et al. 2011; Drago et al. 2013).

12 These results are available upon request. 
On the other hand, it cannot be said that TV3 had an effect on the vote share of CiU in this election. Even though the CiU vote share considerably grew between 1980 and 1984, there is no evidence to claim that this increment is attributable to TV3.

Finally, it is also necessary to find other methodological approaches to examine the causal effect of TV3 on electoral results, especially in more recent years when the controversy about TV3 has been more intense. Since the mid-eighties TV3 covers almost the whole of the Catalan territory, therefore solving the self-selection problem to actually identify the impact of the channel is a challenge. Furthermore, there are much more media sources available today, which boosts competition and increases the possibility for the population to be more and better informed. Implementing rigorous methodological models for analyzing the role of TV3 today will help us to have convincing answers to better understand the role of media in the Catalan politics today.

Note: All data supporting this study are provided as supplementary information accompanying this paper.

\section{Compliance with ethical standards}

Conflict of interest The author declares that he has no conflict of interest.

Ethical approval This article does not contain any studies with human or animals participants performed by any of the authors.

Informed consent This article does not contain any information that requires informed consent.

Open Access This article is distributed under the terms of the Creative Commons Attribution 4.0 International License (http://creativecommons.org/licenses/by/4.0/), which permits unrestricted use, distribution, and reproduction in any medium, provided you give appropriate credit to the original author(s) and the source, provide a link to the Creative Commons license, and indicate if changes were made.

\section{Appendix 1: Results of regional elections in Catalonia (vote share in parenthesis)}




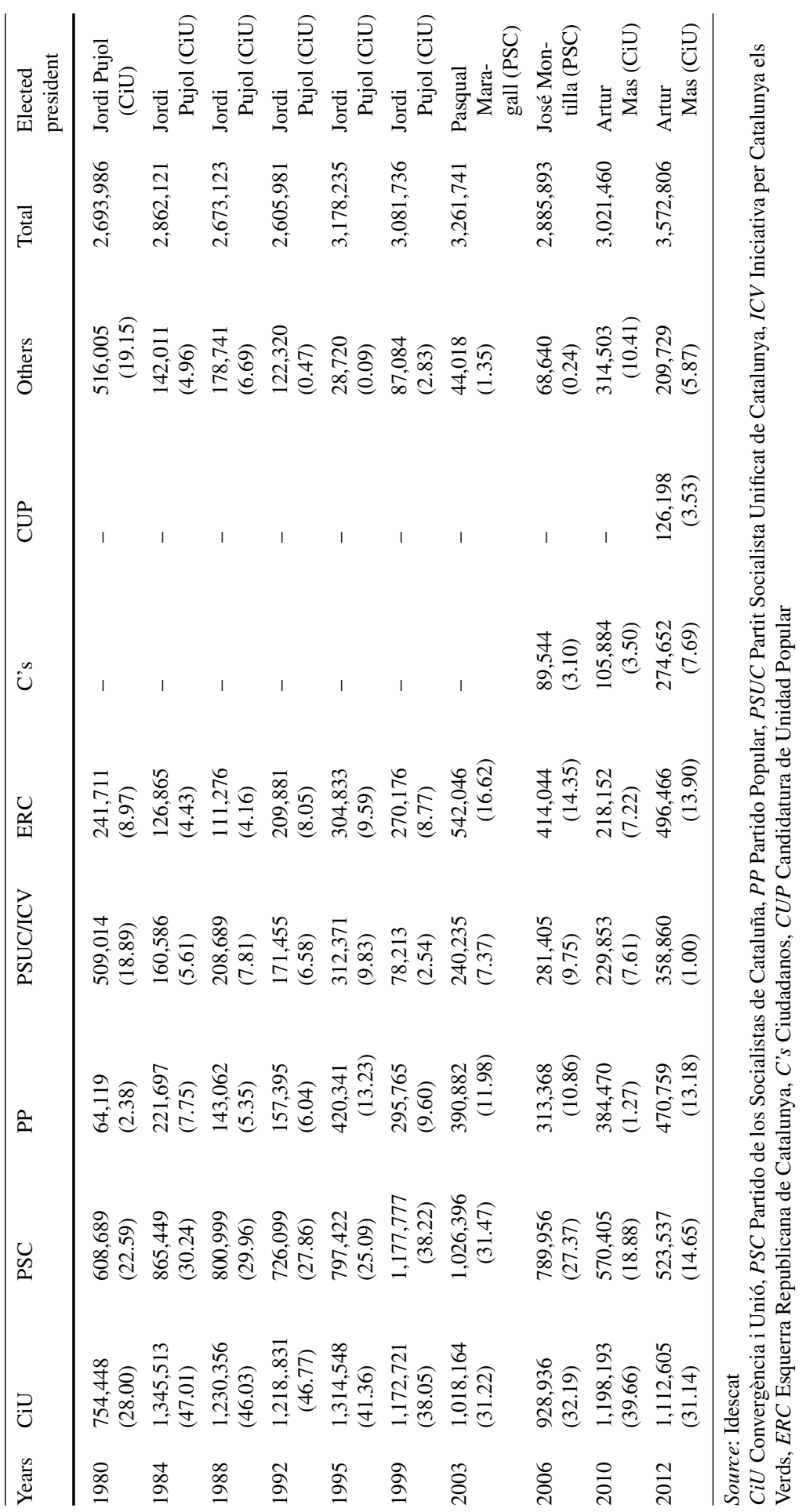




\section{Appendix 2: Methodological issues about the construction of the treatment and control groups}

\section{Sources}

The treatment and control groups were constructed using information from two main sources: (1) Information on TV3 coverage from the newspaper La Vanguardia from January 2 1984, to July 271985 (see table below), and (2) a report about the history of TV3: Montero (1987). Televisió de Catalunya.

Information on TV3 coverage from newspaper La Vanguardia

\begin{tabular}{lcl}
\hline Date & Page & Article \\
\hline Monday, January 02, 1984 & 42 & TV Catalana 1983: un año de grandes esperanzas \\
$\begin{array}{l}\text { Friday, January 06 1984 } \\
\text { Friday, January 13 1984 }\end{array}$ & 19 & $\begin{array}{l}\text { TV3 llegó a las comarcas de Lleida } \\
\text { El repetidor de TV3 en Rocacorba no cubrirá todas } \\
\text { las comarcas de Girona } \\
\text { Los hoteleros de la Vall d'Aran se quejan de las } \\
\text { anomalías de TV }\end{array}$ \\
$\begin{array}{l}\text { Thursday, April 05 1984 } \\
\text { Saturday, April 07 1984 }\end{array}$ & 23 & $\begin{array}{l}\text { Las islas Baleares quieren “conectar" con TV3 } \\
\text { TVE y TV3 estudian la cobertura del Pallars Sobira } \\
\text { yhursday, June 13 1985 Vall d'Aran }\end{array}$ \\
Wednesday, June 26 1985 & 29 & $\begin{array}{c}\text { A partir de septiembre, TV3 se captará en buenas } \\
\text { condiciones en toda la zona del Pirineo } \\
\text { La polítca de reemisores de TV3 perjudica los } \\
\text { acuerdos con TVE, según Calviño }\end{array}$ \\
Saturday, July 27 1985 & 23 & $\begin{array}{c}\text { Calviño inauguró ayer un centro emisor en el } \\
\text { Pirineo leridano }\end{array}$ \\
Saturday, July 27 1985 & 19 &
\end{tabular}

\section{Procedure}

Both La Vanguardia and Montero (1987) provide information about the timing of the introduction of TV3. Both sources give information about the availability date of broadcasting towers and the coverage of these towers at district level in some cases, and at municipality level in others. Therefore, there some methodological issues that is worth mentioning:

(a) In most of cases, the information says that TV3 reached district $\mathrm{X}$ in a specific day $Y$.

(b) Thus, if some source says that district $\mathrm{X}$ was covered by TV3 in a day prior to 29 April 1984 (day of the 1984 Catalan parliamentary election), then all its municipalities are classified as treated, and the districts that are not mentioned being covered prior to 29 April 1984 are classified as untreated (control group).

(c) However, both sources also provide information about the impossibility of taking TV3 to some municipalities within some districts that were covered by TV3 before 
29 April 1984 (treatment group) due to geographical issues (i.e. see articles by La Vanguardia of Thursday, April 51984 Wednesday, June 26 1985).

(d) When it is possible to identify which municipalities within treated districts are not covered by TV3 before 29 April 1984 (treatment group), these municipalities are moved to the control group.

(e) Additionally, as explained in the empirical strategy section, a Propensity Score Matching method is applied to make treatment and control groups more comparable. After PSM is implemented, 30 municipalities of the treatment group are out of the sample (out of the "common support" in the jargon of PSM).

Using such procedure, we construct the treatment and control groups. The result is presented in the following table:

Number of municipalities by district included as control and treated

\begin{tabular}{|c|c|c|c|}
\hline District & $\begin{array}{l}\text { Number of } \\
\text { municipalities }\end{array}$ & Total treated & Total control \\
\hline Alt Camp & 23 & 23 & 0 \\
\hline Alt Empordà & 68 & 65 & 3 \\
\hline Alt Penedès & 27 & 27 & 0 \\
\hline Alt Urgell & 19 & 0 & 19 \\
\hline Alta Ribagorça & 3 & 0 & 3 \\
\hline Anoia & 33 & 33 & 0 \\
\hline Bages & 35 & 34 & 1 \\
\hline Baix Camp & 28 & 26 & 2 \\
\hline Baix Ebre & 13 & 0 & 13 \\
\hline Baix Empordà & 36 & 34 & 2 \\
\hline Baix Llobregat & 29 & 29 & 0 \\
\hline Baix Penedès & 14 & 0 & 14 \\
\hline Barcelonès & 5 & 5 & 0 \\
\hline Berguedà & 30 & 0 & 30 \\
\hline Cerdanya & 16 & 0 & 16 \\
\hline Conca de Barberà & 22 & 0 & 22 \\
\hline Garraf & 6 & 6 & 0 \\
\hline Garrigues & 24 & 24 & 0 \\
\hline Garrotxa & 21 & 21 & 0 \\
\hline Gironès & 27 & 27 & 0 \\
\hline Maresme & 30 & 28 & 2 \\
\hline Montsià & 12 & 0 & 12 \\
\hline Noguera & 30 & 29 & 1 \\
\hline Osona & 51 & 50 & 1 \\
\hline Pallars Jussà & 14 & 0 & 14 \\
\hline Pallars Sobirà & 15 & 0 & 15 \\
\hline Pla d'Urgell & 16 & 0 & 16 \\
\hline
\end{tabular}




\begin{tabular}{lccc}
\hline District & $\begin{array}{l}\text { Number of } \\
\text { municipalities }\end{array}$ & Total treated & Total control \\
\hline Pla de l'Estany & 11 & 0 & 11 \\
Priorat & 23 & 0 & 23 \\
Ribera d'Ebre & 14 & 0 & 14 \\
Ripollès & 20 & 0 & 20 \\
Segarra & 21 & 21 & 0 \\
Segrià & 37 & 36 & 1 \\
Selva & 26 & 22 & 3 \\
Solsonès & 15 & 0 & 15 \\
Tarragonès & 20 & 20 & 0 \\
Terra Alta & 12 & 0 & 12 \\
Urgell & 20 & 20 & 0 \\
Val d'Aran & 9 & 0 & 9 \\
Vallès Occidental & 22 & 22 & 2 \\
Vallès Oriental & 42 & 42 & 305 \\
Total & 938 & 633 & \\
\hline
\end{tabular}

\section{Appendix 3: Propesity score matching}

We use a Logit model to estimate the propensity scores of areas exposed and not exposed to TV3 (see Table below). In this model we include co-variates as initial conditions that jointly influence the likelihood of treatment and outcomes.

Logit Model of the Availability of TV3 in April 1984

\begin{tabular}{lc}
\hline Co-variates & Marginal effects \\
\hline Voter Turnout 1980 & 1.036 \\
CiU Vote Share 1980 & $(1.452)$ \\
& 1.137 \\
Log Total Population 1981 & $(1.360)$ \\
& $0.813^{* *}$ \\
Share of Men 1981 & $(.236)$ \\
Share of Non-native 1981 & 5.671 \\
& $(8.365)$ \\
Share of Catalan Speakers 1981 & 4.305 \\
Share of BUP COU 1981 & $(3.272)$ \\
Share of Mid Graduate 1981 & -2.146 \\
& $(1.671)$ \\
\end{tabular}




\begin{tabular}{lc}
\hline Co-variates & Marginal effects \\
\hline Share of Professional Diploma 1981 & -1.981 \\
& $(16.260)$ \\
Banks 1981 & $-2.111^{* *}$ \\
& $(0.329)$ \\
Distance to Barcelona & $-0.0002 *$ \\
& $(0.0001)$ \\
Constant & -5.379 \\
Prob $>$ chi $^{2}$ & $(5.129)$ \\
Pseudo $\mathrm{R}^{2}$ & 0.000 \\
$\mathrm{~N}$ & 0.433 \\
\hline
\end{tabular}

$* * * 99 \%$ of confidence level, ** 95\%, and * 90\%

Clustered standard errors at district level (in parenthesis)

We estimate the scores ensuring they satisfy the balancing property within the region of common support, which is built by dropping treatment observations whose propensity score is higher than the maximum or less than the minimum propensity score of the controls. 53 treated municipalities are off the common support, whilst no control municipality is off. Then, we match the treatment and control areas using the default Stata Software specifications, namely Epanechnikov kernel matching with a bandwith of 0.06. In the table below, the balancing test for co-variates displays the mean differences for the treatment and control groups before and after being matched. As we see, there was a significant difference in six co-variates between those municipalities exposed to TV3 and those not exposed before matching that were reduced after matching. These are: Voter turnout in 1980, log of total population, share of non-native from Catalonia, share of people with BUP COU education, share of people with mid graduate, and share of people with professional diploma. Once matched, the treatment and control groups are more comparable in terms of the covariates included in the PSM.

Balancing test for control variables used to estimate propensity scores

\begin{tabular}{lrrrrr}
\hline \multicolumn{4}{l}{ Kernel matching } \\
\cline { 2 - 5 } & \multicolumn{1}{l}{ Mean } & & & \\
\cline { 2 - 6 } & Treated & Control & \%Bias & \%Reduct Bias & $\mathrm{p}>|\mathrm{t}|$ \\
\hline Voter Turnout 1980 & & & & & \\
Unmatched & 0.577 & 0.592 & -9.1 & & $0.208^{*}$ \\
Matched & 0.607 & 0.596 & 5.8 & 35.5 & 0.267 \\
CiU Vote Share 1980 & & & & & \\
Unmatched & 0.340 & 0.331 & 4.8 & & 0.488 \\
Matched & 0.359 & 0.354 & 2.5 & 47.3 & 0.662 \\
\hline
\end{tabular}




\begin{tabular}{|c|c|c|c|c|c|}
\hline & \multicolumn{5}{|c|}{ Kernel matching } \\
\hline & \multicolumn{5}{|l|}{ Mean } \\
\hline & Treated & Control & $\%$ Bias & $\%$ Reduct Bias & $\mathrm{p}>|\mathrm{t}|$ \\
\hline \multicolumn{6}{|c|}{ Log Total Population 1981} \\
\hline Unmatched & 6.985 & 6.479 & 34.0 & & $0.000 *$ \\
\hline Matched & 6.701 & 6.596 & 7.0 & 79.3 & 0.181 \\
\hline \multicolumn{6}{|c|}{ Share of Men 1981} \\
\hline Unmatched & 0.503 & 0.509 & -23.2 & & $0.000 *$ \\
\hline Matched & 0.503 & 0.508 & -17.4 & 24.9 & $0.723 *$ \\
\hline \multicolumn{6}{|c|}{ Share of Non-native 1981} \\
\hline Unmatched & 0.169 & 0.118 & 42.5 & & $0.000^{*}$ \\
\hline Matched & 0.144 & 0.140 & 2.8 & 93.4 & 0.607 \\
\hline \multicolumn{6}{|c|}{ Share of Catalan Speakers 1981} \\
\hline Unmatched & 0.883 & 0.903 & -16.4 & & $0.015^{*}$ \\
\hline Matched & 0.904 & 0.892 & 10.1 & 38.2 & $0.079 *$ \\
\hline \multicolumn{6}{|c|}{ Share of BUP COU 1981} \\
\hline Unmatched & 0.038 & 0.037 & 6.3 & & $0.345^{*}$ \\
\hline Matched & 0.037 & 0.036 & 6.0 & 5.0 & 0.263 \\
\hline \multicolumn{6}{|c|}{ Share of Mid Graduate 1981} \\
\hline Unmatched & 0.016 & 0.014 & 12.3 & & $0.089 *$ \\
\hline Matched & 0.015 & 0.014 & 6.4 & 48.2 & 0.173 \\
\hline \multicolumn{6}{|c|}{ Share of Professional Diploma 1981} \\
\hline Unmatched & 0.015 & 0.012 & 15.9 & & $0.016^{*}$ \\
\hline Matched & 0.014 & 0.013 & 12.1 & 23.8 & 0.017 \\
\hline \multicolumn{6}{|l|}{ Banks 1981} \\
\hline Unmatched & 0.484 & 0.429 & 11.0 & & 0.112 \\
\hline Matched & 0.441 & 0.392 & 9.7 & 11.7 & 0.102 \\
\hline \multicolumn{6}{|c|}{ Distance to Barcelona } \\
\hline Unmatched & 4292.5 & 5723.1 & -46.2 & & $0.000 *$ \\
\hline Matched & 4567.4 & 4723.4 & -5.0 & 98.1 & $0.378^{*}$ \\
\hline
\end{tabular}

$* * * 99 \%$ of confidence level, $* * 95 \%$, and $* 90 \%$

This "bias" is defined as the difference of the mean values of the treatment group and the (not matched/matched) non-treatment group, divided by the square root of the average sample variance in the treatment group and the not matched non-treatment group

Finally, the list of municipalities that are off the common support are presented in the table below. 


\begin{tabular}{|c|c|c|c|c|c|c|c|}
\hline \multirow[t]{2}{*}{ District } & \multirow{2}{*}{$\begin{array}{l}\text { Number of } \\
\text { municipalities }\end{array}$} & \multicolumn{3}{|l|}{ Treated } & \multicolumn{3}{|l|}{ Control } \\
\hline & & $\begin{array}{l}\text { Total } \\
\text { treated }\end{array}$ & $\begin{array}{l}\text { On } \\
\text { common } \\
\text { support }\end{array}$ & $\begin{array}{l}\text { Off } \\
\text { common } \\
\text { support }\end{array}$ & $\begin{array}{l}\text { Total } \\
\text { control }\end{array}$ & $\begin{array}{l}\text { On } \\
\text { common } \\
\text { support }\end{array}$ & $\begin{array}{l}\text { Off } \\
\text { common } \\
\text { support }\end{array}$ \\
\hline Alt Camp & 23 & 23 & 23 & 0 & 0 & 0 & 0 \\
\hline Alt Empordà & 68 & 65 & 65 & 0 & 3 & 3 & 0 \\
\hline Alt Penedès & 27 & 27 & 27 & 0 & 0 & 0 & 0 \\
\hline Alt Urgell & 19 & 0 & 0 & 0 & 19 & 19 & 0 \\
\hline Alta Ribagorça & 3 & 0 & 0 & 0 & 3 & 3 & 0 \\
\hline Anoia & 33 & 33 & 30 & 3 & 0 & 0 & 0 \\
\hline Bages & 35 & 34 & 33 & 1 & 1 & 1 & 0 \\
\hline Baix Camp & 28 & 26 & 26 & 0 & 2 & 2 & 0 \\
\hline Baix Ebre & 13 & 0 & 0 & 0 & 13 & 13 & 0 \\
\hline Baix Empordà & 36 & 34 & 33 & 1 & 2 & 2 & 0 \\
\hline Baix Llobregat & 29 & 29 & 14 & 15 & 0 & 0 & 0 \\
\hline Baix Penedès & 14 & 0 & 0 & 0 & 14 & 14 & 0 \\
\hline Barcelonès & 5 & 5 & 0 & 5 & 0 & 0 & 0 \\
\hline Berguedà & 30 & 0 & 0 & 0 & 30 & 30 & 0 \\
\hline Cerdanya & 16 & 0 & 0 & 0 & 16 & 16 & 0 \\
\hline Conca de Barberà & 22 & 0 & 0 & 0 & 22 & 22 & 0 \\
\hline Garraf & 6 & 6 & 4 & 2 & 0 & 0 & 0 \\
\hline Garrigues & 24 & 24 & 24 & 0 & 0 & 0 & 0 \\
\hline Garrotxa & 21 & 21 & 21 & 0 & 0 & 0 & 0 \\
\hline Gironès & 27 & 27 & 26 & 1 & 0 & 0 & 0 \\
\hline Maresme & 30 & 28 & 24 & 4 & 2 & 2 & 0 \\
\hline Montsià & 12 & 0 & 0 & 0 & 12 & 12 & 0 \\
\hline Noguera & 30 & 29 & 29 & 0 & 1 & 1 & 0 \\
\hline Osona & 51 & 50 & 49 & 1 & 1 & 1 & 0 \\
\hline Pallars Jussà & 14 & 0 & 0 & 0 & 14 & 14 & 0 \\
\hline Pallars Sobirà & 15 & 0 & 0 & 0 & 15 & 15 & 0 \\
\hline Pla d'Urgell & 16 & 0 & 0 & 0 & 16 & 16 & 0 \\
\hline Pla de l'Estany & 11 & 0 & 0 & 0 & 11 & 11 & 0 \\
\hline Priorat & 23 & 0 & 0 & 0 & 23 & 23 & 0 \\
\hline Ribera d'Ebre & 14 & 0 & 0 & 0 & 14 & 14 & 0 \\
\hline Ripollès & 20 & 0 & 0 & 0 & 20 & 20 & 0 \\
\hline Segarra & 21 & 21 & 21 & 0 & 0 & 0 & 0 \\
\hline Segrià & 37 & 36 & 35 & 1 & 1 & 1 & 0 \\
\hline Selva & 26 & 22 & 22 & 0 & 3 & 3 & 0 \\
\hline Solsonès & 15 & 0 & 0 & 0 & 15 & 15 & 0 \\
\hline Tarragonès & 20 & 20 & 19 & 1 & 0 & 0 & 0 \\
\hline Terra Alta & 12 & 0 & 0 & 0 & 12 & 12 & 0 \\
\hline
\end{tabular}




\begin{tabular}{|c|c|c|c|c|c|c|c|}
\hline \multirow[t]{2}{*}{ District } & \multirow{2}{*}{$\begin{array}{l}\text { Number of } \\
\text { municipalities }\end{array}$} & \multicolumn{3}{|l|}{ Treated } & \multicolumn{3}{|l|}{ Control } \\
\hline & & $\begin{array}{l}\text { Total } \\
\text { treated }\end{array}$ & $\begin{array}{l}\text { On } \\
\text { common } \\
\text { support }\end{array}$ & $\begin{array}{l}\text { Off } \\
\text { common } \\
\text { support }\end{array}$ & $\begin{array}{l}\text { Total } \\
\text { control }\end{array}$ & $\begin{array}{l}\text { On } \\
\text { common } \\
\text { support }\end{array}$ & $\begin{array}{l}\text { Off } \\
\text { common } \\
\text { support }\end{array}$ \\
\hline Urgell & 20 & 20 & 20 & 0 & 0 & 0 & 0 \\
\hline Val d'Aran & 9 & 0 & 0 & 0 & 9 & 9 & 0 \\
\hline Vallès Occidental & 22 & 22 & 12 & 10 & 0 & 0 & 0 \\
\hline Vallès Oriental & 42 & 42 & 34 & 8 & 2 & 2 & 0 \\
\hline Total & 934 & 633 & 576 & 53 & 305 & 305 & 0 \\
\hline
\end{tabular}

\section{References}

Albertson B, Lawrence A (2009) After the credits roll: the long-term effects of educational television on public knowledge and attitudes. Am Polit Res 37(2):275-300

Barone G, D'Acunto F, Narciso G (2012) Telecracy: testing for channels of persuasion. Trinity College Dublin Working Paper 0412

Clots-Figueras I, Masella P (2013) Education, language and identity. Econ J 123:332-357

DellaVigna S, Gentzkow M (2010) Persuasion: empirical evidence. Annu Rev Econ 2:643-669

DellaVigna S, Kaplan E (2007) The FOX news effect: media bias and voting. Q J Econ 122(3):1187-1234

DellaVigna S, Kaplan E (2008) The political impact of media bias. In: Islam R (ed) Information and public choice: from media markets to policy making. World Bank, Washington, pp 79-105

Downs A (1957) An economic theory of democracy. Harper \& Row, New York

Drago F, Nannicini T, Sobbrio F (2013) Meet the press: how voters and politicians respond to newspaper entry and exit. IZA Discussion Paper 7169

Enikolopov R, Petrova M, Zhuravskaya E (2011) Media and political persuasion: evidence from Russia. Am Econ Rev 101(7):3253-3285

Feddersen TJ, Pesendorfer W (1996) The swing voter's curse. Am Econ Rev 86:408-424

Feddersen TJ, Pesendorfer W (1997) Voting behaviour and information aggregation in elections with private information. Econometrica 67:1029-1058

Gentzkow M (2006) Television and voter turnout. Q J Econ CXXI:931-972

Gentzkow M, Shapiro JM (2009) Media market structure and political participation: historical evidence from U.S. newspapers. Unpublished Manuscript. University of Chicago

Gentzkow M, Shapiro J, Sinkinson M (2011) The effect of newspaper entry and exit on electoral politics. Am Econ Rev 101(7):2980-3018

George L, Waldfogel L (2008) National media and local political participation: the case of the New York Times. In: Islam R (ed) Information and public choice: from media markets to policymaking. World Bank, Washington

Gerber AS, Green DP (2000) The effects of canvassing, telephone calls and direct mail on voter turnout: a field experiment. Am Polit Sci Rev 121:653-663

Gerber AS, Karlan D, Bergan D (2009) Does the media matter? A field experiment measuring the effect of newspapers on voting behavior and political opinions. Am Econ J Appl Econ 1(2):35-52

Geys B (2006a) 'Rational' theories of voter turnout: a review. Polit Stud Rev 4:16-35

Geys B (2006b) Explaining voter turnout: a review of aggregate-level research. Elect Stud 25:637-663

Green DP, Gerber AS (2001) Getting out the youth vote: results from randomized field experiments. Yale University, New Haven

Green DP, Gerber AS, Nickerson DW (2003) Getting out the vote in local elections: results from six door-to-door canvassing experiments. J Polit 65(4):1083-1096

Hierro MJ (2012) Change in national identification: a study of the catalan case. Ph.D. Thesis. Universidad Autónoma de Madrid 
Jones DE (2007) Pujol y la construcción de un espacio catalán de comunicación: interacciones entre instituciones políticas y empresas mediáticas (1980-2003). Ámbitos 16:499-524

Kern HL, Hainmueller J (2009) Opium for the masses: how foreign media can stabilize authoritarian regimes. Polit Anal 17(4):377-399

Khandker SR, Koolwal GB, Samad HA (2010) Handbook of impact evaluation. World Bank, Washington

Matsusaka J (1995) Explaining voter turnout patterns: an information theory. Public Choice 84(1-2):91-117

Montero E (1987) Televisió de Catalunya. Televisió de Catalunya S.A, Barcelona

Oberholzer-Gee F, Waldfogeland J (2010) Media markets and localism: does local news in spanish boost hispanic voter turnout? Am Econ Rev 99(5):2120-2128

Prat A, Strömberg D (2013) The political economy of mass media. Working paper, LSE and IIES

Snyder JM, Strömberg D (2010) Press coverage and political accountability. J Polit Econ 18(2):355-408

Sobbrio F (2014) The political economy of news media: theory, evidence and open issues. In: Forte F, Mudambi R, Navarra PM (eds) A handbook of alternative theories of public economics. Edward Elgar Pub, Cheltenham, pp 278-320

Sørensen R (2016) The impact of state television on voter turnout. Br J Political Sci. https://doi.org/10.10 $17 / \mathrm{S} 000712341600048 \mathrm{X}$

Strömberg D (2004) Radio’s impact on public spending. Q J Econ 119(1):189-221

Strömberg D (2015) Media and politics. IIES, Stockholm University, Stockholm

White S, Oates S, McAllister I (2005) Media effects and russian elections, 1999-2000. Br J Polit Sci 35(2):191-208

Woolard KA, Gahng T-J (1990) Changing language policies and attitudes in autonomous Catalonia. Lang Soc 19(3):311-330

Publisher's Note Springer Nature remains neutral with regard to jurisdictional claims in published maps and institutional affiliations. 